\title{
The food limitation hypothesis for juvenile marine fish
}

\author{
Olivier Le Pape ${ }^{1, *}$, Sylvain Bonhommeau ${ }^{2}$
}

\author{
1 AGROCAMPUS OUEST, UMR985 ESE Ecologie et santé des écosystèmes, Rennes, France \\ 2 IFREMER UMR EME 212, Sète, France

\begin{abstract}
:
Coastal zones are productive areas that serve as nursery grounds for a large number of marine species. However, the processes involved in survival success during the juvenile phase are not wellknown. Some authors suggest that the availability of prey is important to support the production of prerecruit fish whose fitness is enhanced through optimal feeding conditions. Accordingly, recruitment is limited by the carrying capacity of the nursery habitat. In contrast, other authors state that the carrying capacity of the nursery grounds is not fully exploited, suggesting that there is no effect of food limitation. This study combines an overview of the literature, focused on flatfish that are especially dependent on coastal and estuarine nursery grounds, an extension to other marine fishes and a modelling approach on growth and survival of juvenile fish to explore the controversy of food limitation in their nursery grounds. We demonstrate that the relative lack of growth limitation observed for young marine fishes at the individual scale is related to an observational bias: fish have been affected by size-selective mortality linked to food limitation, but only surviving individuals are observed. As the population is skewed towards the faster-growing juveniles, the growth of survivors remains close to optimal, even when food resources are limited. Food limitation is of major influence in determining the carrying capacity of the nursery habitat. To sustain marine fish populations and related fisheries, management action is needed to protect coastal and estuarine areas and maintain or restore nursery productivity.
\end{abstract}

Keywords: Estuaries and coasts ; food limitation ; habitat functionality ; juvenile fish growth ; sizedependent mortality ; trophic capacity of nursery habitat 
2 The life strategy of most marine teleost fish species is characterized by high fecundity, the 3 production of large amounts of small pelagic eggs and the lack of parental care (Juanes 2007).

4 This strategy leads to high mortality in early life stages (eggs, larvae and juveniles). Survival5 to-maturity rates as low as 1:100,000 are common in many marine fish populations (Table 1).

6 This low survival rate is specific to marine fish, as freshwater and anadromous species exhibit 7 higher likelihood of surviving from egg to adult (e.g., 1\% survival for Atlantic salmon (Salmo 8 salar, Salmonidae) populations; Hutchings and Jones 1998). A life strategy with high and 9 highly variable mortality makes the survival of eggs, larvae (Houde 1987, 2008, Cushing 1995, Bakun 1996) and juveniles (Sogard 1997) strongly dependent on abiotic and biotic environmental factors. This, in turn, results in high variability in the recruitment and mortality

12 of early life stages with dramatic influence on the abundance of fish populations (Gallego et al. 2012). Most of the recruitment variability of marine fishes (10-fold interannually and 100-

14 fold in overall variability; Houde 2008) is explained by larval and juvenile survival rates 15 (Levin and Stunz 2005). These stages represent a bottleneck in the dynamics of fish populations and small changes in the survival rates of these stages can cause large differences

17 in recruitment (Levin and Stunz, 2005; Daewel et al. 2011). Recruitment variability and the associated large fluctuations in fish populations have been a focus of marine and fisheries science since in the early $20^{\text {th }}$ century (Hjort 1914) and continue to be important areas of research (Sinclair 1997, Houde 2008, Gallego et al. 2012).

21 The egg and larvae stage and the juvenile stage both exhibit low survival and 22 contribute to the large recruitment variability: - The variability-generating processes that occur at the egg and larval stages are of 24 critical importance to population levels (Hjort 1914, van der Veer et al. 2000a, Rochette et al. 
1 2012; Table 1). During these life stages, complex and varied mechanisms influence both

2 growth and survival and are important determinants of recruitment success. These include the

3 drift of eggs and larvae, temperature control over early life dynamics (i.e., life stage duration,

4 growth and mortality), food availability for larvae and predation. These mechanisms interact

5 to generate recruitment variability that can fluctuate by an order of magnitude (Houde 2008).

- Mortality rates of the juvenile stage are also high (Table 1), though significantly

7 lower than the larval stage (van der Veer et al. 2000a). Processes occurring in the nursery

8 habitat are important determinants of population density (Holbrook et al. 2000). Minto et al.

9 (2008) investigated the link between survival variability and population density from stock

10 recruitment relationships using both a modelling approach and a meta-analysis of wild fish

11 populations. They show that the interannual variability of progeny survival increases at low

12 adult abundance. This pattern is consistent with density-dependent mortality in the juvenile

13 phase which follows stochastic density-independent mortality in the egg and larval stages.

14 Thus, density-independent and -dependent effects on settlement, growth and mortality in the

15 nursery habitat influence recruitment success and variability (van der Veer et al. 2000a,

16 Peterson et al. 2000, Peterson 2003, Levin and Stunz 2005, Fodrie et al. 2009) and are

17 important in regulating year-class strength (Scharf 2000, Stottrup and Sparrevohn 2007). As

18 described in the concentration hypothesis, recruitment variability is lower in populations with

19 large density-dependent effects (Iles and Beverton 2000) related to the capacity and features

20 of the nursery habitat (Johnson 2007). This is especially verified for flatfishes (Iles and

21 Beverton 2000, Le Pape et al. 2003c, Rooper et al. 2004). Thus, nursery habitats are

22 particularly important for many marine fish species (Peterson et al, 2000, Beck et al. 2001

23 Fulford et al. 2011) and can act as habitat bottlenecks.

24 Though growth limitation and mortality on nursery grounds are thought to contribute

25 to recruitment variability (Rauck and Zijlstra 1978, Karakiri et al. 1989, Cowan et al. 2000, 
1 Grover et al. 2002, Duncan and Holland 2006), survival processes of the juvenile phase are

2 still not well known and remain controversial in regards to their contribution to recruitment 3 variability.

- According to many analyses, prey availability is important to sustain production of

5 pre-recruit fishes and juveniles. Coastal and estuarine (C\&E) habitats (mudflats, salt marshes,

6 kelp forests, seagrass beds, mangroves, coral reefs, upwelling regions, etc; Vasconcelos et al.

7 in press), but also other productive habitats, serve as nursery grounds for many marine fish

8 species (Able et al. 1999, Elliott and Dewailly 1995, Holbrook et al. 2000, Grover et al. 2002,

9 Jones et al. 2002, Laegdsgaard and Johnson 2001, Peterson 2003, McLusky and Elliott 2004,

10 Elliott et al. 2007, Franco et al. 2008, Selleslagh and Amara, 2008), and especially flatfishes

11 (Gibson 1994, Meng et al. 2002, Le Pape et al. 2003b). Fishes aggregate in these productive

12 areas where their fitness is enhanced through optimal growth from better feeding conditions

13 (Blaber and Blaber 1980, Miller et al. 1984, Gibson 1994, Friedland et al. 1996, Beck et al.

14 2001, Houde 2008). The interannual distribution of food availability and juvenile fish biomass

15 are synchronous (Fujii and Noguchi 1995, Walsh 1996, Vinagre et al. 2005, Wouters and

16 Cabral 2009). Thus, food resources are often mentioned as a limiting factor in the capacity of

17 nursery habitats (van der Veer and Witte 1993, Gibson 1994, Craig et al. 2007, Nash and

18 Geffen 2000, Nash et al. 2007).

19 - Other studies show that juvenile growth is not affected by trophic conditions in 20 nursery habitats, indicating that there is no effect of food limitation (Curran and Able 2002, 21 Ross 2003, Hampel et al. 2005, Diaz et al. 2011; Selleslagh et al., 2012) and suggesting that 22 the carrying capacity of nursery areas is not reached (Rogers 1994, Shi et al. 1997, van der 23 Veer et al. 2000a, Vinagre and Cabral 2008). Van der Veer et al. (2000b) and Manderson et 24 al. (2000) propose predation as the main factor in the variability of juvenile mortality and 25 recruitment success, suggested for various species (McErlean et al. 1973, Blaber and Blaber 
1 1980, Riley et al. 1981, Gibson 1994, Levin et al. 1997, Wennhage and Gibson 1998, Halpin

2 2000, Lewis 2001, Wennhage and Pihl 2001, Hixon and Jones 2005, Baker and Sheaves

3 2005, White and Caselles 2008, Sheaves 2009). Predators and their short-term response (Stier

4 et al. 2013) to juvenile fish densities generate density dependent mortality (Johnson 2007,

5 Juanes 2007), helping to explain why recruitment is dampened during the juvenile stage on

6 nursery grounds.

$7 \quad$ This controversy is illustrated (Table 2) by several well-studied cases of numerous

8 species of the juveniles of commercial flatfish off the Western coasts of Europe (Fig. 1) and

9 other temperate and subarctic areas. In many studies, measures of growth, nutritional

10 condition and body condition indicate almost no food limitation or links to prey availability of

11 the juveniles collected on C\&E nursery grounds during the summer growth period. Moreover,

12 these juveniles appear to be protected from interspecific competition by the process of food

13 partitioning. However, for the same species, study areas and periods, other studies indicate (i)

14 nutritionally-limiting conditions during metamorphosis, (ii) a small decrease in growth, (iii)

15 an overlap between the juvenile distribution of benthic species and their potential prey and

16 synchronous spatio-temporal variations, (iv) a link between recruitment and food production

17 and (v) density-dependent distribution of juveniles, with an increased range into the open sea

18 for stronger year classes, related to the extension of enriched productive areas. As a

19 consequence, the influence of food limitation on juvenile fishes in their C\&E nursery grounds

20 remains unanswered.

21 The primary aim of this synthesis is to shed light on this question by focusing on 22 temperate and subarctic flatfish (Table 2) that are especially dependent on C\&E nursery 23 grounds (Iles and Beverton, 2000), and extending this focus to other marine fishes (pelagic, 24 demersal and reef associated round fish and sharks, from tropical to subarctic ecoregions). We 25 estimate the influence of trophic limitation on the density-dependent processes involved in 
1 year-class regulation during the juvenile stage of marine fishes in their nursery grounds.

2 Solving this question has implications to understanding the main processes involved in the

3 renewal of fish stocks during the juvenile stage. If food resources are an important regulating

4 factor, the regulation of year-class strength during the juvenile stage depends, at least partly,

5 on the productivity of consumable resources and the related capacity of nursery habitats

6 (Hayes et al. 1996). In this case, maintaining the quality and productivity of essential nursery

7 habitat is critical for the renewal of sustainable fish populations.

\section{The question of food limitation in nursery grounds: the controversy from individual to population scale}

Different and complementary approaches have been used to evaluate the impacts of food limitation on the survival of juvenile fish, from laboratory experiments and mesocosms to in situ gradients at different biological scales: individual (growth, condition), population size (density and distribution) and multispecific scales. Differing results are observed when comparing the different approaches used to analyze the effect of food limitation on nursery grounds.

\section{Experimental approach in the laboratory}

Laboratory experiments enables us to estimate the influence of abiotic factors (e.g., temperature and salinity; Fonds 1975) as well as biotic factors (e.g., the effect of food intake on the growth of young flatfishes). These experiments allow us to develop models (e.g., the metabolic scope for growth, Fonseca et al. 2010, or the Dynamic Energy Budget models, Kooijman 2000, van der Veer et al. 2003) to estimate juvenile flatfish growth with regard to the food supply (Table 2). These models are useful for further comparisons between in situ 
1 growth and estimates of growth based on controlled conditions. The experimental approach

2 demonstrates that food quantity and quality affect juvenile flatfish growth. Limited food

3 resources reduce growth, energy storage and the condition of juvenile flatfish after a few

4 days, with important consequences on juvenile growth and survival, even for short-term

5 events. Accordingly, a meta-analysis of starvation-induced changes in the early stages of

6 fishes from laboratory-controlled experiments, including seven marine species (six round

7 fishes, one flatfish) showed a general rapid exponential decrease of biogeochemical

8 conditions with starvation, immediately followed by death (Meyer et al. 2012), thus extending

9 previous mentioned results to round fishes.

\section{Field experiments}

11 Field experiments are less controlled experimental systems which provide favourable habitats

12 in terms of the main factors governing juvenile fish growth, i.e., hydrodynamic exposure,

13 food availability, predation and water temperature (Gibson 1994). They can serve to bridge

14 the gap between field studies with the inherent difficulties of control, and laboratory experiments that can be standardized and replicated but suffer from a lack of environmental realism (Laffargue et al. 2007). Similarly, caging experiments that consist of stocking fishes

17 in cages placed in the natural environment enables the comparison of growth rates in different habitats and living conditions (Able et al. 1999, Ciotti et al. 2010). However, growth rates of

19 fishes in enclosures or from in situ experiments must be interpreted with caution, as fish 20 movements and the threat of predation may be influential but are not realistically represented 21 (Stunz et al. 2002).

Both types of field experiments demonstrate that patterns in food availability result in

23 differences in growth rates for juvenile fish. They also show competition for food to be the 24 underlying mechanism in determining juvenile growth and survival for various marine fish 
1 species (Sogard 1992, Craig et al. 2007). In accordance with laboratory studies, field

2 experiments confirm that, in spite of a trade-off with other factors and especially the threat of

3 predation (Sogard 1992, Halpin 2000), food availability on the nursery ground is a primary

4 driver of habitat choice and juvenile fitness.

\section{In situ analysis, individual scale}

6 Many field studies have analyzed growth limitation for juvenile wild fishes from individual

7 food intake, growth and individual condition with the primary objective to estimate habitat

8 quality and the link between food availability and living conditions. At this individual scale,

9 food limitation often appears to be of minimal importance for juvenile flatfishes (Table 2).

10 Measures of growth, nutritional condition and body condition indicate neither significant food

11 limitation, nor a link with prey availability or juvenile density. However, some limited signals

12 of limitation can be observed from gut content, recent condition, body condition and lipid

13 reserve, especially just after settlement, with advantages to the first-settled fishes. Juvenile

14 flatfishes appear to be not food limited and comparisons between experimental models and in

15 situ estimates show that coastal nurseries provide a maximal potential for food intake, without

16 negative density-dependent growth. Food limitation in the sense of starvation, individual

17 growth and consumption of the prey of juvenile flatfishes often suggests that the carrying

18 capacity of nursery areas is not reached (van der Veer et al. 1994). Concerning other fish

19 orders (i.e., round fishes), Diaz et al. (2011) provide evidence that the Argentinean anchovy

20 (Engraulls anchoita, Engraulidae) may not be food limited in any of their nursery grounds;

21 juvenile growth and condition do not differ between nursery habitats for two other round fish

22 species (Ross 2003) and individual consumption indicates no effect of food limitation on

23 European sea bass (Dicentrarchus labrax, Moronidae) (Hampel et al. 2005). 
1 On the contrary, some authors reach opposite conclusions from in situ approaches at

2 the individual scale on local habitat. Indeed, significant differences in condition are observed 3 at small scales for juvenile plaice (Table 2). Concerning round fishes, Islam and Tanaka

4 (2005) use RNA:DNA ratios, total protein and growth rates to estimate the proportion of 5 starving juvenile Japanese sea bass (Lateolabrax japonicas, Lateolabracidae) and to show 6 their dependency on prey availability. The condition of juvenile sea bass was not equal 7 throughout the nursery grounds. Fishes in the upper river were in better condition than those 8 in the lower estuary. Juvenile fishes living on prey-impoverished habitats have significantly 9 higher metabolic costs, and thus higher foraging expenses (Goto and Wallace 2010). Lastly, when considering juvenile hammerhead shark (Sphyrna lewini, Sphyrnidae), a non-teleost 11 species with parental care and much larger juvenile individuals, the link between starvation 12 and body condition, i.e., the effect of food limitation, is highly significant (Duncan and 13 Holland 2006).

\section{In situ estimation, population scale}

Contrary to studies of individuals, population-scale in situ studies generally conclude that growth limitation and density-dependent effects on abundance and distribution are linked to competition and mortality related to food limitation. Firstly, limited effects are revealed when flatfish growth is analyzed from the size of individuals in the population (Table 2). With regard to model estimates based on laboratory experiments or to optimal conditions in mesocosms, in situ observations show smaller sizes of flatfish juvenile during part of the growing season in the nursery grounds, with a slight decrease in regards to optimal estimates. A synthesis of Table 2 suggests growth rates that were close to experimental values after settlement but food limitation in summer for large juveniles that had settled a few months previously. These lower growth rates and the related density-dependent regulation suggest 
1 competition for food during the summer growth period. Similarly, growth rates appear to be

2 positively related to food quantity and quality in space and time. Estuarine habitats offer

3 optimal opportunities for flatfish juvenile growth, at least partly due to higher food

4 availability, as growth varies annually with the most important food source in the nursery

5 ground. When considering juvenile round fishes, Phelan et al. (1999) demonstrated that the

6 growth of juvenile tautogs (Tautoga onitis, Labridae) is faster where prey availability is

7 higher. Moreover the average length of juvenile Atlantic cod (Lekve et al. 2002) and red drum

8 (Sciaenops ocellatus, Sciaenida)e (Scharf 2000) decrease with increased density, indicating

9 density-dependent effects. By coupling analyses of growth and density in different estuarine

10 habitats, Sogard (1992) concludes that juvenile fishes of various species are most abundant in

11 habitats that support faster growth.

12 Alternatively, studies which focus on spatial distribution and recruitment success also

13 point out a clear influence of bottom-up food limitation on juvenile flatfishes (Table 2).

14 Especially, a significant relationship is found between fluvial discharge and the abundance of

15 high densities of flatfish juveniles in ecosystems of freshwater influence. This indicates that

16 the freshwater supply helps sustain the ability of estuarine nurseries to support juveniles. The

17 freshwater particulate organic matter propagates up the food web to juvenile flatfish, showing

18 the role of river discharge and terrigeneous subsidy input in the function of nurseries.

19 Richness in organic matter impacts the settling of benthic communities preyed upon by

20 juvenile flatfishes. The influence of terrestrial discharge on juvenile flatfish differs in

21 intensity and spatial extent between years with relation to river inputs and is correlated to the

22 seaward extent of high densities of these juveniles. High land-based run-off is favorable to the

23 productivity of invertebrate prey and consequently to the productivity of flatfish species.

24 Trophic enhancement related to river inputs at least partly influences recruitment. The

25 influence of estuarine organic matter supply for the development of a community that is 
1 tolerant to low salinity and can provide suitable food for juvenile fish were confirmed for

2 round fish species (Costa and Bruxelas 1989, Pasquaud et al. 2008). Similarly, the density

3 dependent distribution of juvenile, from estuaries to open waters, was also verified for round

4 fishes (Bacheler et al. 2012). For instance, juveniles of filter-feeding Atlantic menhaden

5 (Brevoortia tyrannus, Clupeidae) are found to be associated with gradients of phytoplankton

6 biomass in their estuarine nurseries along the Eastern coast of the USA (Friedland et al.

7 1996). When densities of juveniles are pooled for all marine species, the maximum juvenile

8 density is observed in the middle mesohaline region of estuaries (Nicolas et al. 2010). The

9 amount of organic matter is the highest in these areas and conditions are particularly suitable

10 for the development of benthic invertebrate prey (Moore 1978, Elliott and Taylor 1989). This

11 high abundance of benthic prey leads to high fish density, especially of juvenile marine

12 species (Courrat et al. 2009). Accordingly, a human-induced limitation of the river flow that

13 lowered the primary production of the adjacent shelf is found to negatively impact the

14 recruitment of the European anchovy population in the Gulf of Cadiz (Ruiz et al. 2009).

15 Likewise, severe droughts can reduce primary productivity in estuaries, with cascading effects

16 on higher trophic levels, food availability and juvenile survival for various fish species (Wetz 17 et al. 2010).

18 The relationship between food availability and juvenile flatfish abundance (Table 2)

19 and distribution are also confirmed outside regions of freshwater influence. In coastal areas,

20 the migrations of juvenile flatfish demonstrate the influence of foraging opportunities on daily

21 movements. At larger (i.e., seasonal to annual) time scales, their distribution match the

22 distribution of their prey. Similarly, the interannual variation of abundance and distribution of

23 juvenile flatfish are synchronous with those of the macrobenthos (Table 2). The density-

24 dependent distribution of juveniles that extends to deeper water when abundance increases in 
1 their C\&E nurseries is also verified for Atlantic cod on North West Atlantic coast (Swain 2 1993).

3 For flatfishes, local population density is a trade-off between larval supply and high 4 mortality rates (Nash et al. 2007). Accordingly, competition for a limited food resource is one 5 of the main causes of restocking failure in coastal stock enhancement programs (Stottrup and 6 Sparrevohn 2007). The survival rate of hatchery-reared fish is first related to the number of 7 larvae released and then to the total (wild and hatchery-reared) recruitment intensity, 8 indicating that there are limits in the carrying capacity of nursery grounds (Goto 2006). White 9 and Cazelles (2008) examine the effect of density-dependent processes linked to larval supply and habitat capacity on post-settlement interactions in juvenile reef fish. They estimate that 11 the abundance of juvenile fish is not limited by the larval supply at low densities of recruits, 12 but by density-dependent competition for food resources and shelter at high densities of 13 recruits. However, other studies that estimate total consumption in C\&E nursery grounds 14 using growth, daily food consumption and density find that food is abundant enough to 15 sustain juvenile growth for flatfish (Table 2), suggesting that the carrying capacity of nursery 16 areas is not reached.

17 Thus, using population approaches, even if opposite conclusions are sometimes 18 reached, density-dependent growth and mortality related to food availability appear to be major factors controlling recruitment success of juvenile stages (Juanes 2007).

\section{In situ, interspecific competition}

21 Many studies of C\&E flatfish nurseries demonstrate that if numerous species use the same 22 nursery area, they develop strategies of resource partitioning to avoid food limitation and 23 niche overlap. Species, but also different cohorts or age groups of a given species, had 24 specialized their feeding behavior, with only a moderate niche overlap. Differences in feeding 
1 rhythms, habitat use, and food preference reduce food competition (Table 2). More generally,

2 when all fish species are considered, niche overlaps vary: they are higher between species of

3 the same family but remain limited (Pasquaud et al. 2010b). Juvenile fish of different species

4 avoid competing for food resources even if competition is observed between resident species

5 (Lafaille et al. 2000).

Resource partitioning, indicative of competition (Nunn et al. 2012), is a strategy to

7 optimize food availability and appears as an adaptation to limited food resources that allows

8 coexistence of species within the nursery zone. Such partitioning results from the long term

9 natural selection of a trophic strategy. Indeed, there is no need to avoid niche overlap if food

10 supply exceeds the need of the different species. This conclusion is reinforced by ontogenic

11 shifts from higher overlap in diets of larval fish, to lower overlap in diets of juvenile fish,

12 enabling competition avoidance between different size and age classes of the same species

13 (Nunn et al. 2012). Geange and Stier (2009) analyze the timing of settlement on coral reef

14 systems and find that species survive best in the absence of competitors and that survival

15 declines when species enter the community later than their competitors. These interspecific

16 effects related to settlement time provide additional evidence of the importance of

17 competition in nursery areas.

18 In spite of some intra-scale discrepancies, different approaches that measure common

19 parameters such as growth, condition, density or distribution allow us to draw different

20 conclusions about food limitation. Laboratory and field experiments, in situ studies at

21 population scales and interspecific competition show a significant influence of food limitation

22 on juvenile fish growth and survival. In situ studies that focus on individuals lead mainly to

23 opposite conclusions; growth of juvenile fishes, especially small juvenile fishes, on the

24 nursery grounds does not appear to be food limited. These opposing conclusions are obvious

25 for populations of juvenile flatfishes on C\&E areas (Table 2). However, they are verified 
1 elsewhere for other fish species in different types of nursery habitats, from tropical to

2 subarctic ecoregions.

3

4

5

6

\section{Bridging the gap between the different approaches and scales}

\section{and their opposing conclusions}

Size-selective mortality in juvenile stages of teleost fish is critical (Sogard 1997). If direct evidence of density-dependent competition for food is weak (Cowan et al. 2000), especially on an individual scale, the influence of food limitation on juvenile fish growth and survival becomes obvious when changes in the size distribution associated with mortality are distinguished from changes due to individual growth.

\section{Size-dependent mortality during juvenile life stages}

A range of daily mortality as high as $5-40 \%$, with a mean of $18 \%$ (Selleslagh 2008), is observed for the Eastern Channel plaice during the highly sensitive post-settlement period (Geffen et al. 2007, Nash and Geffen, 2012). The same level of mortality is estimated for tropical reef fishes (9-20\%; Juanes 2007). Such high mortality rates for newly-settled larvae are far from specific to flatfishes and reef fishes, i.e., Atlantic cod shows even higher mortality rates at the juvenile stage (Houde 2002; Table 1).

These high mortality rates during the juvenile stages appear to select the faster growing individuals (Hovenkamp 1992, Houde 1997, Marchand et al. 2003, Craig et al. 2007, Juanes 2007, Selleslagh 2008). Natural mortality rates decline dramatically with increasing body size (Houde 1987, Miller et al. 1988, Conover 2007), leading to size-selective processes: as individuals grow rapidly, they spend less time in the smallest size classes that are most vulnerable to predation (Sogard 1997). For example, growth of anchovies in the Bay of 
1 Biscay was investigated using the otolith growth data collected during repeated larval and

2 juvenile surveys on spawning and nursery grounds (Allain et al. 2003). The surviving

3 juveniles show much faster growth rates during their larval period than the pool of larvae

4 from which they originate, indicating dramatic growth-selective survival. Similarly, Atlantic

5 cod have a high potential for growth- and starvation-induced mortality (Daewell et al. 2011).

6 Lekve et al. (2002) demonstrate that the size distribution of juvenile Atlantic cod is skewed to

7 the larger size classes on nursery grounds, indicating size-selective mortality. This skewness

8 increases with increased density in relation to density-dependent processes. More generally,

9 size distribution of juvenile fish within a cohort is strongly influenced by intraspecific

10 competition for resources, often leading to skewed frequency distributions (Ohlberger et al.

11 2012). The aforementioned studies and numerous others mentioned in Sogard (1997) provide

12 evidence that body size during the juvenile stages is a major determinant of survival. Thus,

13 the disproportionate removal of small fish causes an overestimation of growth rates if it is

14 based only on survivors (Sogard 1997).

15 Two explanations have been proposed to explain this size-selective mortality.

16 - Firstly, survival of larger fish is enhanced because larger members of a cohort can

17 better tolerate physical extremes and endure longer periods without food (Sogard 1997). A

18 lack of food affects energetic reserves of individuals and makes them more sensitive to other

19 sources of mortality (Nash et al. 2007). Faster growing juveniles gain survival advantages via

20 resistance to starvation and also through the ability of larger individuals to ingest a wider

21 variety of prey (Salgado et al. 2004; Nunn et al. 2012). Rapid growth provides a size

22 advantage in which larger fish have stronger competitive effects (Geange and Stier 2009).

23 - Secondly, predation is a significant size-selective process, especially for early stages,

24 as predation mortality is directly determined by fish size, with decreasing mortality rates with

25 the increasing size (van der Veer et al. 1994). Slow-growing and small fish remain vulnerable 
1 to predation for a longer period (i.e., the stage duration hypothesis; Sheperd and Cushing

2 1980, Houde 1987; Anderson 1988). For example, individuals of newly metamorphosed

3 demersal fish, e.g., plaice (Gibson et al. 1995, Gibson and Robb 1996), are subject to strong

4 size-selective predation by crangonid shrimp (Crangon crangon, Crangonidae) (Burrows et

5 al. 2001), which primarily consume fish $<30 \mathrm{~mm}$ (van der Veer et al. 1997). Accordingly,

6 Ellis and Gibson (1995) estimate that flatfish reaching $45 \mathrm{~mm}$ are at much lower risk from

7 predators. More generally, after the dramatic decline in natural mortality with increasing size

8 in early life stages, a lower but steadier density level is maintained for large juveniles of

9 marine fish species (Conover 2007, Dingsor et al. 2007). Thus, growth limitation influences

10 body size and affects resistance to unfavorable environment factors and to food limitation. It

11 also affects foraging ability and vulnerability to predation, which in turn influence individual

12 fitness (Ohlberger et al. 2012) and recruitment.

\section{The link between size-dependent mortality and growth explains the}

\section{hidden effect of food limitation at individual scales}

Average growth rates of fish larvae and juveniles are lower under food-limited conditions (Houde 2008). As demonstrated for larvae in the stage duration hypothesis (Sheperd and Cushing 1980, Houde 1987), mortality rates of juvenile fish are inversely related to size and linked to growth. According to the "bigger is better hypothesis", mortality and predation during young fish stages are related to nutritional deficiencies (Miller et al. 1988, Sogard 1997, Suthers 1998).

This link could explain why food limitation effects are not obvious for very young fishes. If there is high mortality of starving juveniles, a disproportionate removal of small fish causes an overestimation of the population mean growth rate from the size of survivors, which could be misleading (Houde 2008). As the population is skewed toward faster growing 
1 juveniles, the growth of survivors could be close to experimental values under optimal 2 conditions (Table 2), even when food limitation is important. The relationship between food 3 availability and size-dependent mortality hinders variability in growth by selecting faster4 growing individuals and dampening recruitment variability. This also helps explain why the 5 relationship between the mean length of a cohort and the year class strength appears to be 6 relatively weak (van der Veer et al. 1994), even if food limitation alters growth performance 7 (dynamic self-thinning, Nash et al. 2007). Similarly, this could explain why estimates of the 8 total food consumption by juvenile fish over the summer period suggest that food is abundant 9 enough to sustain juvenile growth (Table 2). The juvenile population size, in abundance, is adapted to the available food after the high mortality period during the first post-settlement stages. Growth limitation is more obvious for larger fish with lower mortality rates, e.g., 1 year old juvenile common sole (Le Pape et al. 2003a) or sharks (Duncan and Holland 2006).

\section{Testing the food limitation hypothesis using simulations}

Using a simulation framework, we test if, in conditions of limited food, the growth curve that is observed at the population scale during the first months of juvenile growth differs from the theoretical optimal growth curve. For illustrative purposes, we choose the life history traits of common sole and simulate a population of one million larvae.

\section{Model}

Individuals of the population grow according to a von Bertalanffy equation:

$$
L_{i, a}=L_{i n f} \cdot \varepsilon_{1}(a)-\left(L_{i n f} \cdot \varepsilon_{1}(a)-L_{0}\right) e^{\left(-k \cdot t \cdot \varepsilon_{2}(a)\right)}
$$

where $t$ is the time (in months), $L_{i, a}$ is the length (in $\mathrm{cm}$ ) of the individual $i$ at age $a$ (in months since metamorphosis), $L_{\text {inf }}$ is the maximal length (i.e., $54 \mathrm{~cm}$; Fishbase.org), $L_{0}$ is the length at metamorphosis $(0.5 \mathrm{~cm}$; Fonds 1979$), k$ is the growth rate (0.26; Fishbase.org). $\varepsilon_{1}(a)$ and $\varepsilon_{2}(a)$ 
1 are random noise that have a normal distribution with a mean equal to 1 and a standard

2 deviation equal to 0.1 (i.e., $10 \%$ noise). This random noise is added to $\mathrm{k}$ and $L_{\text {inf }}$ to account

3 for inter-individual variability. The growth of one million fish over their first year (from

4 metamorphosis in the spring to the end of the year) is described in the size-at-age matrix $\left(\mathrm{L}_{\mathrm{i}, \mathrm{a}}\right)$.

5 Two scenarios are developed: (S1) there is no food limitation and the growth is simulated as

6 in Eq. 1. Ten thousand individuals are then randomly sampled in the population to simulate a

7 survey. (S2) Food limitation is simulated. As food limitation is shown to decrease the

8 maximal length (e.g., Kooijman 2010), a negative offset is subtracted from the infinite length.

9 This offset corresponds to $20 \%$ of the maximal length $\left(L_{i n f},=43.2\right)$. Individuals die following

10 a size-related natural mortality as defined by Gislason et al. (2010). This mortality is defined

11 for each individual for each age in a mortality-at-age matrix $\left(\mathrm{M}_{\mathrm{i}, \mathrm{a}}\right)$ :

$M_{i, a}=0.55-1.61 . \log \left(L_{i, a}\right)+1.44 . \log \left(L_{i n f}\right)+\log (k)$

13 where $\mathrm{M}_{i, a}$ is the instantaneous mortality rate per year of the individual $i$ at age $a$ (in months)

14 and for its size, $L_{i, a}$.

15 The probability of survival of each individual per month is directly calculated from the

16 mortality-at-age matrix with the equation $S_{i, a}=e^{-M_{i, a}}$. Over the first six months of the

17 juvenile stage, the estimate of survival is about $10 \%$, which is in accordance with estimates

18 for the common sole (Rochette et al. 2013). The survival probability, $\mathrm{S}_{i, a}$, is then used to

19 define the probability that an observer would sample the larva $i$ at age $a$ in the wild. Ten

20 thousand fish were sampled within the whole population using the survival probability as a

21 weighting.

$22 \quad$ Results

23 For the two scenarios, the sampled population has an estimated mean length within the 24 same range as the theoretical growth curve (Fig. 2). If sampling occurs over the whole 25 population without accounting for the individual mortality (S1), the length of individuals is 
1 randomly distributed over the theoretical growth curve. As only survivors are observed or

2 sampled in S2 (food limitation scenario; Fig. 2b), individuals having a slower growth rate due

3 to food limiting conditions are not sampled or are sampled less often. The mean length of

4 sampled individuals in S2 is very similar to the theoretical growth curve but the distribution is

5 less variable and skewed, with lower a longer tail towards higher lengths, corresponding to

6 the observation made for Atlantic cod by Lekve et al. (2002). This simulation demonstrates

7 the bias of in situ sampling; as only survivors are observed, i.e., juveniles with the fastest

8 growth; thus, the sampling is biased towards fast-growing individuals (Fig. 2b). This shows

9 that even in food-limited conditions, one observes individuals close to the theoretical growth

10 curve.

Thus, the synthesis of different approaches and scales demonstrates both the trophic limitation in C\&E nursery areas and the lack of an obvious signal when food limitation is observed on survivors at the individual scale. Though the present approach is at first focused on temperate and subarctic flatfish, further extension to other marine fishes (pelagic, demersal

16 and reef associated round fish, from tropical to subarctic ecoregions) allows us to broaden these conclusions. As hypothesized by Gibson (1994), food appeared to be the main factor affecting juvenile fish concentration in nursery grounds. Juvenile fish growth is related to food availability, and its limitation interacts with other factors, such as size- (growth) dependent predation (Wennhage 2000) and mortality (Sogard 1997) to determine survival rates. Moreover, the negative relationship between growth and the duration of life stages 22 increases the period when mortality and predation are higher for food limited juveniles. Thus, 23 food limitation affects both the duration of the juvenile stage and the survival during this 24 stage (Sheperd and Cushing 1980, Houde 1987, van der Veer et al. 1994). 


\section{The influence on fish populations of trophic limitation and habitat} capacity in C\&E nursery grounds

An obvious but variable dependency of juvenile fish on the productivity of $C \& E$ essential habitats

Juvenile fish of many species aggregate in productive C\&E nursery areas in order to enhance their fitness (Blaber and Blaber 1980, Miller et al. 1984, Gibson 1994, Beck et al. 2001). Habitat suitability, which is linked to production and food quality and availability, is highly influential on the spatio-temporal patterns of juvenile fish (Holbrook et al. 2000, Nicolas et al. 2007). Though trophic limitation is a primary factor in determining the suitability of nursery habitat, juvenile fish-habitat interactions are complex (Fulford et al. 2011). Habitat suitability is a trade-off between habitat selection, foraging quality and predator avoidance (Sogard 1992, Wennhage and Gibson 1998, Laegdsgaard and Johnson 2001, Able 2005, Sheaves 2009). The level of juvenile dependence on trophic limitation varies with time, among cohorts (i.e., density-dependent variations related to interannual variations in settled larvae; Fig. 3) and even among subcohorts during the settlement period (Fonseca et al. 2006, Geange and Stier 2009, Nash and Geffen 2012, Geffen et al. 2011). This dependence varies at small spatial scales and between different nursery habitats of the same population (Nash et al. 2007, de Raedemaecker et al. 2011), with relations to juvenile density and food availability. It also varies between different populations of the same species, e.g., the influence of food limitation appears significantly higher for plaice in the Irish Sea (Nash and Geffen 2000) relative to those in the North Sea (van der Veer et al. 1986) or in the Wadden Sea (van der Veer et al. 2000a). Finally, it varies from one species to another, even in the same area, e.g., in the North Sea, trophic dependence is important for common sole (van der Veer et al. 2001) but limited for plaice (van der Veer et al. 1986). 


\section{An influence on marine fish population renewal}

3 For a fish population to persist, habitat must be available to sustain all periods of development

4 (Nunn et al. 2012). As such, the capacity of nursery habitats is a key contributor to the overall

5 population fitness (Fodrie et al. 2009), stability and extinction risk (Ohlberger et al. 2012).

6 Nash et al. (2007) provide evidence of self-thinning for plaice at the local population scale:

7 when juvenile population density is high, food limitation depends on the number of

8 individuals that settle relative to the productivity of the nursery ground. Populations that

9 strictly depend on limited nursery habitats approach the carrying capacity of the habitat, at least when settlement is high. Post-settlement survival depends on nursery habitat size and

11 productivity, in relation to the amount of larval settlement (Rooper et al. 2004, Johnson 2007,

12 Nash et al. 2007). Thus, fish populations are limited by the quantity and quality of habitat and

13 food available for juvenile fishes (Nunn et al. 2012). Food dependent size-selective mortality

14 dampens the variability in size distribution and reduces among-year variability in recruitment strength (van der Veer et al. 1994, Le Pape et al. 2003b, Minto et al. 2008). Accordingly, habitat bottlenecks have been identified for juvenile fish stages of species or populations for

17 which the variation in habitat quality has a disproportionate effect on renewal (Fulford et al. 2011). This dependence appears especially important for C\&E nursery dependent flatfish species (Iles, 1994), but is also of important concern for many other fishes. Iles and Beverton

20 (2000) demonstrate that nursery-dependent species at high spawning stock biomass have asymptotic stock recruitment relationships, with a maximum recruitment level hiding a linear relationship to spawning biomass (i.e., the concentration hypothesis). These species depend

23 on the capacity of nursery habitats for their recruitment (Fig. 3): density-dependent processes 24 are at least partly linked to prey resources that regulate recruitment strength and dampen 
1 recruitment variability (Cowan et al. 2000, van der Veer et al. 2000a, Le Pape et al. 2003c,

2 Houde 2008, Minto et al. 2008).

3 Thus, if variability-generating processes operating at the egg and larval stages are of

4 major importance, processes occurring during the juvenile stage are also important in

5 determining recruitment strength (van der Veer et al. 2000a) and variability (Iles and

6 Beverton 2000, Minto et al. 2008). Among these juvenile processes, density-dependent effects

7 related to food limitation appear to be a main governing factor (Cowan et al. 2000).

8 Nevertheless, food limitation influence differs for different species, populations, cohorts,

9 nursery habitats, and years in relation to the balance between juvenile density and food

10 availability (van der Veer et al. 2000a, Nash and Geffen 2000, Nash et al. 2007).

\section{The critical first juvenile stages}

The present synthesis provides evidence of trophic limitation on juvenile marine fishes in their $\mathrm{C} \& \mathrm{E}$ nursery grounds but the question remains for which juvenile stage(s) this limitation constrains the recruitment strength.

The transition phase, after the last larval metamorphosis (Geffen et al. 2007), is demonstrated to be a critical stage (Juanes 2007), and thus demands thorough attention (Nash and Geffen 2012). Indeed, for the juvenile stages, density-dependent processes in young fish survival decline as they grow (Dingsor et al. 2007), with an especially dramatic decline of mortality with increasing body size (Houde 1987, Miller et al. 1988). Size-selective mortality appears to be mainly restricted to the first year of life (van der Veer et al 1994) and is especially high during the first juvenile stages. Indeed, during ontogeny at young stages, both improvements in vision and swimming performances and increases in gape size lead to shifts in diet composition and a larger choice of prey (Nunn et al. 2012). The density-dependent 
1 regulation of a cohort derived from a reduction in prey resources is hypothesized to occur at a

2 critical size and/or weight following the larval settlement (van der Veer 1986, Houde 1997,

3 Cowan et al. 2000; Nash and Geffen 2012). Fish are most vulnerable in the period following

4 the larval settlement, as the lack suitable prey due to their limited predation abilities,

5 potentially leading to either reduced growth or starvation, reduce survival (Nunn et al. 2012).

6 This limitation occurs when densities of fish populations and consumption of resources

7 remain high relative to the prey density and the replenishment rate (Cowan et al. 2000, Nash

8 et al. 2007), and before the shift in resource use (Nunn et al, 2012) and the drop in

9 vulnerability. At young stages, the decline in prey density by juvenile consumption is large

10 enough to result in density-dependent effects, as is demonstrated in several cases studies

11 (Cowan et al. 2000).

In summary, after an exponential decrease in mortality with body size/weight

13 (Conover 2007), fish reach a body size related both to lower predation and to an increase in

14 prey size, energy content and availability (i.e., a larger choice of species item and size spectra,

15 Nunn et al. 2012), and mortality is dramatically reduced (Ellis and Gibson 1995, Gibson et al.

16 1995). Thus, a dramatic regulation of the size of a population occurs for the lowest juvenile

17 size (Dingsor et al. 2007) during the critical period (Houde, 2008) when mortality is high

18 enough to sharply modulate the population via limited food resources (Fig. 3). Indeed,

19 density-dependent processes influence year-class strength mainly during the first weeks after

20 settlement in the nurseries (van der Veer 1986, Rijnsdorp et al. 1992). 
3 The present synthesis focuses on the important influence of the biotic habitat capacity, i.e.,

4 food availability, on the early life stages of fish (Rijndorp et al. 1992, Schmitt and Holbrook

5 2000, Johnson 2007, Nash et al. 2007, Hayes et al. 2009). Recruitment strength and

6 population dynamics are strongly determined by the productivity and food resources in C\&E

7 nursery habitats. Maintaining large and high quality nursery habitats should be a primary

8 focus to preserve fish species whose population range depends on the trophic capacity of their

9 habitat at the juvenile stage (Hodgson et al. 2011, van de Wolfshaar et al. 2011). There is a

\section{The need to preserve the functionality of $C \& E$ nursery habitats for} marine fish population renewal need for protection of the quality and productivity of nursery habitats to maintain fish stock renewal. The nutrient supply from $\mathrm{C} \& \mathrm{E}$ areas stimulates primary production, which supplies food sources for larvae and juveniles, consequently, sustains the related fisheries (Beck et al. 2001, Lamberth et al. 2009, Sheaves et al. 2009). Quantitative and qualitative factors related to anthropogenic disturbances influence the capacity of $\mathrm{C} \& \mathrm{E}$ nurseries and, thus, the recruitment and the renewal of populations (Cowan et al. 2000, Meng et al. 2000, Peterson et al. 2000, Peterson 2003, Phelan et al. 2000, Scharf 2000, Rochette et al. 2010). It is important to maintain a high ecological quality of essential nursery habitat in $C \& E$ areas in order to sustain marine populations and fisheries. Measures aiming at improving or preserving the capacity of juvenile habitat are the most effective for improving adult biomass of populations regulated by density dependence during the juvenile phases (van de Wolfshaar et al. 2011). Preservation and rehabilitation measures should be designed to provide nursery habitats for fishes and enhance their food base (Nunn et al. 2012). Nursery function must be accounted for in monitoring systems of C\&E waters to maintain high ecological status (Beck et al. 2001) and especially for the establishment of MPAs to provide and export juveniles, to enhance fishing yields (Pelletier and Magal 1996, Gell and Roberts 2003, Kaplan 2009) and benefit the 
1 fisheries (Mesnildrey et al. 2013).

2

3

4

5

\section{Estimating habitat suitability from large juvenile fish growth and} density: an appropriate tool

The density, growth and condition of juvenile fishes are relevant indicators to estimate the ecological quality of nursery habitats (e.g., Guindon and Miller 1995, Suthers 1998, Able et al. 1999, Duffy-Anderson and Able 1999, Phelan et al. 2000; Selleslagh and Amara, 2013). However, as starving and newly-settled juveniles are removed from the population by high mortality rates, growth rates are overestimated for very young stages and cannot be used as indicators of the nursery function. With regards to high mortality rates of post-settlement juvenile fishes in relation to the nutritional deficiencies of their nursery grounds (i.e., the food limitation hypothesis, Fig. 3), it could be misleading to determine essential nursery habitats and estimate their quality from the density and growth of newly post-settled fish.

In contrast, large juveniles experience dramatically lower mortality and it is more reliable to collect data on larger juvenile fish to identify nursery habitat and estimate its ecological status. Indeed, density is less variable, food limitation is more obvious (Duncan and Holland 2006), and growth is less biased due to size-dependent selection (Meng et al. 2000, Le Pape et al. 2003a, Gilliers et al. 2006, Amara et al. 2007, Amara et al., 2009; Selleslagh and Amara, 2013). Nevertheless, biased and incorrect decisions regarding habitat quality can still be made when using a growth-based assessment without identifying factors, such as temperature and density, that may underlie differences in growth rates (Searcy et al. 2007).

A given habitat is considered a nursery if it contributes disproportionately to the size and number of adults relative to other juvenile habitats (Beck et al. 2001). The most 
1 environmentally-sensitive fish populations are those whose nursery areas are restricted to a

2 few coastal sites (Parrish et al. 1997). The identification of these sites is an important

3 consideration for coastal management (Cogan et al. 2009, Vasconcelos et al. 2011,

4 Vasconcelos et al. in press). During the settlement period, the high spatiotemporal variability

5 in juvenile abundance linked to both the pulses of larval supply and high mortality rates (Nash

6 et al. 2007) leads to spurious estimates of juvenile abundance and habitat capacity. On the

7 contrary, the abundance of juvenile fish is dramatically less variable after larval settlement

8 and the huge decline in mortality caused by the dampening effects of density-dependent

9 processes (Iles and Beverton 2000, Rooper et al. 2004, Johnson 2007). At this older juvenile

10 stage, the habitat contribution to the population, i.e., the total biomass of individuals added to

11 adult populations (Beck et al. 2001) from a given habitat, can be estimated from juvenile

12 abundance. It is possible to quantify essential and effective juvenile habitats (i.e., the overall

13 contribution from specific habitats to the adult population; Dahlgren et al. 2006), from habitat

14 suitability models (Norcross et al. 1997, 1999, Guisan and Zimmermann 2000, Beck et al.

15 2001, Le Pape et al. 2007, Stoner et al. 2007, Dahlgren et al. 2006) and related mapping

16 approaches (Le Pape et al. 2003b, Fodrie and Mendoza 2006, Rotenberry et al. 2006,

17 Trimoreau et al. in press). Such procedures can be based on populations but can also be

18 estimated from a multimetric index for a more general definition of the essential fish habitats

19 of C\&E ecosystems (Courrat et al. 2009, Delpech et al. 2010). Policy objectives, such as the

20 sustainability of fish resources, ecosystem health or the design of MPAs, should be based on

21 quantitative maps of essential fish habitats (Cogan et al. 2009; Johnson et al; 2012).

22 Furthermore, quantitative indices of habitat suitability can be useful tools to assess the

23 vulnerability of fishes to various anthropogenic disturbances (Steizenmuller et al. 2010), such

24 as habitat loss and degradation linked to xenobiotics (Rochette et al. 2010) or invasive species

25 (Kostecki et al. 2011). 


\section{Conclusion and suggestions for future research}

3 The aim of the present synthesis is to shed light on the controversy of food limitation for

4 juvenile fishes in their C\&E nursery grounds and to analyze the related consequences for

5 survival and future recruitment. We demonstrate that the relative lack of observed growth

6 limitation for young fishes at the individual scale in their nursery grounds is at least partly

7 related to size-selective mortality affecting food-limited and newly-settled fishes (Sogard

8 1992). This synthesis confirms the conclusions of studies that use different approaches (i.e.,

9 experiments on individual juvenile fishes and in situ observations at the population scale) and

10 enhances the understanding of the strategy of food partitioning developed between age groups

11 and between species to limit competition for food resources. Though the present approach

12 focuses on temperate and subarctic flatfish for illustration purposes, a large amount of

13 references to other marine fishes allows us to extend these conclusions to other fish species,

14 and especially to the large proportion of C\&E nursery dependent fishes (Beck et al. 2001).

15 The food limitation hypothesis is such: juveniles aggregate in C\&E productive areas

16 where their fitness is enhanced through better feeding conditions and optimal growth (Beck et

17 al. 2001). Food limitation is of major importance in determining the nursery habitat capacity

18 (Nash et al. 2007). Nevertheless, this influence can vary between species, populations, cohorts

19 (and even subcohorts), locations and years (van der Veer et al. 2000a). Habitat structure,

20 refuge opportunities and connectivity between habitats modulate this ecological function

21 (Able 2005, Sheaves 2009).

22 This synthesis provides enough information to demonstrate the influence of the 23 productivity of C\&E nursery habitats on the recruitment of fish populations (Rijnsdorp et al.

24 1992, Gibson 1994, Iles and Beverton 2000). After the nursery stage, juvenile fish move out 
1 of C\&E ecosystems to join and sustain fish populations on the continental shelf (Beck et al.

2 2001, Sheaves 2009). Breaking closure of life history cycle causes severe problems and C\&E

3 habitat degradation is one of the most serious threats to the recovery of fish stocks. There is a

4 need to maintain and restore the ecological function of $\mathrm{C} \& \mathrm{E}$ nursery grounds to sustain

5 marine fish populations and related fisheries (Hall 1998, Elliott et al. 2007). Spatial and

6 temporal relationships between fisheries species and habitats must be included in fisheries

7 management plans (Peterson 2003). In this context, an important challenge is to account for

8 nursery function in MPA designs to protect juvenile fish from various anthropogenic

9 pressures. To that aim, observations of in situ density and growth of relatively large and old

10 juvenile fish could provide useful tools when density estimates become reliable and size-

11 selective mortality is not hindered by food limitation. Data on these large juveniles could be

12 used to develop habitat suitability models to identify and map essential nursery habitats and to

13 estimate indicators of ecological status for these essential fish habitats.

14 Nevertheless, the underlying ecological processes are still unknown and further studies

15 are needed for young juvenile stages when food limitation is mostly influential (Cowan et al.

16 2000, Juanes 2007, Vasconcelos et al. in press; Fig. 3). It is critical to investigate the

17 dependence level of recruitment on food availability and the variability of this dependence

18 (e.g., interannual or interspecific). In forthcoming research, there is a need to focus on the

19 young post-settlement stage to understand the trophic dependence of juvenile fish on their

20 nursery grounds (Able 2005), as this is one life stage that has not received enough study

21 (Nash and Geffen 2012, Vasconcelos et al. in press). However, the study of food availability

22 for these very young fish remains a challenge and requires a fine analysis of biological and

23 ecological processes to determine the critical stage and to understand the trophic limitation.

24 The uncertainty of the precise life stage on which to focus, the high spatiotemporal variability

25 in both larval supply and mortality (and, thus, density) and the high turnover rate of fish and 
1 small invertebrate prey during the first juvenile stages requires data with small time steps

2 (Fonseca et al. 2006, Geange and Stier 2009, Nash and Geffen 2012) and fine spatial scales

3 (de Raedemaecker et al. 2011; Johnson et al. 2012). Moreover, as the main governing process

4 varies among species and even among populations (Van der Veer et al. 2000a), solving the

5 problem with a general explanation may be an unrealistic goal. Numerous specific case

6 studies are necessary before drawing generic conclusions on the trophic limitations of fish

7 populations.

8

9

\section{Acknowledgements}

This paper was made possible by many colleagues in France, and also in Denmark, the Netherlands, Norway, Portugal, Sweden, the UK, and the USA, and especially but not limited to the flatfish ecology community who were involved in fruitful discussions that helped us to generate and organize ideas. We would like to especially thank Yves Désaunay, IFREMER and Rachid Amara, Université du littoral. We would also like to thank the PhD students who were associated with two decades worth of advances in this research topic: Philippe Riou, Camille Gilliers, Caroline Kostecki, Sébastien Rochette and Benoit Archambault. A special thanks to Sophie Pasquier for editing and Anne Elise Nieblas for multiple thorough English language editing. We also would like to thank to the editor and the three anonymous reviewers for their helpful advice and significant improvements of the manuscript.

\section{References}

Able, K.W. (2005) A re-examination of fish estuarine dependence: Evidence for connectivity between estuarine and ocean habitats. Estuarine, Coastal and Shelf Science 64, 5-18. 
1 Able, K.W., Manderson, J.P. and Studholme, A.L. (1999) Habitat quality for shallow water

2 fishes in an urban estuary: the effects of man-made structures on growth. Marine Ecology

$3 \quad$ Progress Series 187, 227-235.

4 Allain, G. (2004) Modélisation biophysique pour la prévision du recrutement. $\mathrm{PhD}$ thesis,

5 Agrocampus Ouest, Rennes, France.

6 Allain, G., Petigas, P., Grellier, P. and Lazure, P. (2003) The selection process from larval to

7 juvenile stages of anchovy (Engraulis encrasicolus) in the Bay of Biscay investigated by

8 Lagrangian simulations and comparative otolith growth. Fisheries Oceanography 12, 4079418.

10 Amara, R. (2004) 0-group flatfish growth conditions on a nursery ground (Bay of Canche,

11 Eastern English Channel). Hydrobiologia 518, 23-32.

12 Amara, R. and Galois, R. (2004) Nutritional condition of metamorphosing sole: spatial and 13 temporal analyses. Journal of Fish Biology 64, 72-88.

14 Amara, R., Laffargue, P., Dewarumez, J.M., Maryniak, C., Lagardère, F. and Luczac, C.

15 (2001) Feeding ecology and growth of 0-group flatfish (sole, dab and plaice) on a nursery

16 ground (southern Bight of the North sea). Journal of Fish Biology 58, 788-803.

17 Amara, R., Lagardère, F., Désaunay, Y. and Marchand, J. (2000) Metamorphosis and 18 estuarine colonisation in the common sole, Solea solea (L.): implications for recruitment 19 regulation. Oceanologica Acta 23, 469-483.

20 Amara, R., Meziane, T., Gilliers, C., Hermel, G. and Laffargue, P. (2007) Growth and 21 condition indices in juvenile sole Solea solea measured to assess the quality of essential fish 22 habitat. Marine Ecology Progress Series 351, 201-208.

23 Amara, R., Selleslagh, J., Billon, G. and Minier, C. (2009) Growth and condition of 0-group 24 European flounder, Platichthys flesus as indicator of estuarine habitat quality. Hydrobiologia $25 \quad 627,87-98$. 
1 Anderson, J.T. (1988) A review of size dependent survival during pre-recruit stages of fishes

2 in relation to recruitment. Journal of Northwest Atlantic Fishery Science 8, 55-66.

3 Bacheler, N., Buckel, J., Paramore, L. (2012) Density-dependent habitat use and growth of an

4 estuarine fish. Canadian Journal of Fisheries and Aquatic Science 69, 1734-1747.

5 Baker, R. and Sheaves, M. (2005) Redefining the piscivores assemblage of shallow estuarine

6 nurseery habitats. Marine Ecology Progress Series 291, 197-213.

7 Bakun, A. (1996) Patterns in the ocean: Ocean processes and marine population dynamics.

8 San Diego, University of California Sea Grant.

9 Beck, M.W., Heck, K.L., Able, K.W., Childers, D.L., Eggleston, D.B., Gillanders, B.M.,

10 Halpern, B., Hays, C.G., Hostino, K., Minello, T.J., Orth, R.J., Sheridan, P. and Weinstein,

11 M.P. (2001) The role of nearshore ecosystems as fish and shellfish nurseries. Bioscience 51,

$12 \quad 633-641$.

13 Bell, J., Bartley, D., Lorenzen, K. and Loneragan, N. (2006) Restocking and stock

14 enhancement of coastal fisheries: Potential, problems and progress. Fisheries Research 80, 1158 .

16 Blaber, S.J.M. and Blaber, T.G. (1980) Factors affecting the distribution of juvenile estuarine 17 and inshore fish. Journal of Fish Biology 17, 143-162.

18 Bonhommeau, S., Le Pape, O., Tréguier, A.M., Blanke, B., Grima, N., Gascuel, D., Vermard, 19 Y. and Rivot, E. (2009) Estimates of the mortality and the duration of the trans-Atlantic 20 migration of European eel leptocephali using a particle tracking model. Journal of Fish 21 Biology 74, 1891-1914.

22 Burrows, M.T., Gontarek, S.T.J., Nash, R.D.M., Gibson, R.N. (2001) Shrimp predation on 023 group plaice: contrasts between field data and predictions of an individual based model. 24 Journal of Sea Research 45, 243-254. 
1 Cabral, H.N. (2000) Comparative feeding ecology of sympatric Solea solea and S.

2 senegalensis, with in the nursery areas of the Tagus estuary, Portugal. Journal of Fish Biology

$357,1550-1562$.

4 Cabral, H.N. and Costa, M. (1999) Differential Use of Nursery Areas Within the Tagus

5 Estuary by Sympatric Soles, Solea solea and Solea senegalensis. Environmental Biology of

6 Fishes 56, 389-397.

7 Cabral, H.N., Vasconcelos, R., Vinagre, C., França, S., Fonseca, V., Maia, A., Santos, P.R.,

8 Lopes, M., Ruano, M., Campos, J., Freitas, V., Santos, P.T. and Costa, M.J. (2007) Relative

9 importance of estuarine flatfish nurseries along the Portuguese coast. Journal of Sea Research $10 \quad 57,209-217$.

11 Chittaro, P., Finley, R. and Levin, P. (2009) Spatial and temporal patters in the contribution of 12 fish from their nursery habitats. Oecologia 160, 49-61.

13 Ciotti, B.J., Targett, T.E., Nash, R.D.M., Batty, R.S., Burrows, M.T., Geffen, A.J. (2010)

14 Development, validation and field application of an RNA-based growth index in juvenile 15 plaice Pleuronectes platessa. Journal of Fish Biology 77, 2181-2209.

16 Ciotti, B.J., Targett, T.E.R., Burrows, M.T., (2013). Spatial variation in growth rate of early

17 juvenile European plaice Pleuronectes platessa. Marine Ecology Progress Series 475, 213$18 \quad 232$.

19 Ciotti, B., Targett, T., and Burrows, M. (2013) Decline in growth rate of juvenile European 20 plaice (Pleuronectes platessa) during summer at nursery beaches along the west coast of 21 Scotland. Canadian Journal of Fisheries and Aquatic Sciences 70, 720-34.

22 Cogan, C., Todd, B., Lawton, P. and Noji, T. (2009) The role of marine habitat mapping in 23 ecosystem based management. ICES Journal of Marine Science 66, 2033-2042.

24 Conover, D.O. (2007) Nets versus nature. Nature 450, 179-180. 
1 Costa, M.J. and Bruxelas, A. (1989) The structure of fish communities in the Tagus Estuary,

2 Portugal and its role as nursery for commercial fish species. Scientia Marina Topics in

3 Marine biology (eds J.D. Ros) 53, 561-566.

4 Courrat, A., Lobry, J., Nicolas, D., Laffargue, P., Amara, R., Lepage, M., Girardin, M. and Le

5 Pape, O. (2009) Anthropogenic disturbance on nursery function of estuarine areas for marine

6 species. Estuarine, Coastal and Shelf Science 81, 179-190.

7 Cowan, J.H., Rose, K.A. and de Vries, D.R. (2000) Is density dependent growth in young of 8 the year fishes a question of critical weight? Reviews of Fish Biology and Fisheries 10, 61989.

10 Craig, J.K., Rice, J.A., Crowder, L.B. and Nadeau, D.A. (2007) Density dependent growth 11 and mortality in an estuary-dependent fish: an experimental approach with juvenile spot 12 Leiostomus xanthurus. Marine Ecology Progress Series 343, 251-262.

13 Curran, M.C. and Able, K.W. (2002) Annual stability in the use of coves near inlets as 14 settlement areas for Winter Flounder (Pseudopleuronectes americanus). Estuaries 25, 227 15234.

16 Cushing, D. (1995) Population production and regulation in the Sea: a fishery perspective. 17 Cambridge university press, Cambridge.

18 Daewel, U., Peck, M. and Shrum, C. (2011) Life history strategy and impacts of 19 environmental variability on early life stages of two marine fishes in the North Sea: an 20 individual based modelling approach. Canadian Journal Fisheries and Aquatic Sciences 68, $21 \quad 426-443$.

22 Dahlgren, C.P., Kellison, G.T., Adams, A.J., Gillanders, B.M., Kendall, M.S., Layman, C.A., 23 Ley, J.A., Nagelkerken, I. and Serafy, J.E. (2006) Marine nurseries and effective juvenile 24 habitats: concepts and applications. Marine Ecology Progress Series 312, 291-295. 
1 Darnaude, A. (2005) Fish ecology and terrestrial carbon use in coastal areas: implications for

2 marine fish production. Journal of Animal Ecology 74, 864-876.

3 Darnaude, A.M., Harmelin-Vivien, M.L. and Salen-Picard, C. (2001) Food partitionning

4 among flatfih (Pisces: Pleuronectiforms) juveniles in a mediterranean coastal shallow sandy

5 area. Journal of the Marine Biogical Association of the United Kingdom 81, 119-127.

6 Darnaude, A.M., Salen-Picard, C., Polunin, N. and Harmelin-Vivien, M.L. (2004)

7 Trophodynamic linkage between river runoff and coastal fishery yield elucidated by stable

8 isotope data in the Gulf of Lions (NW Mediterranean). Oecologia 138, 325-332.

9 De Raedemaecker, F., Keating, J., Brophy, D., O’Connor, I. and Mc Grath, D. (2011) Spatial

10 variability in diet, condition and growth of juvenile place (Pleuronectes platessa) at sandy

11 beach nursery grounds on the south-west coast of Ireland. Journal of the Marine Biological

12 Association of the UK 91, 1215-1223.

13 Delpech, C., Courrat, A., Pasquaud, S., Lobry, J., Le Pape, O., Nicolas, D., Girardin, M.,

14 Boët, P. and Lepage, M. (2010) Development of a fish-based index to assess the ecological

15 quality of transitional waters: The case of French estuaries. Marine Pollution Bulletin 60,

$16908-918$.

17 description, calibration, and sensitivity analysis. Ecological Modelling 202, 144-164.

18 Diaz, M.P.M., Olivar, M., Martos, P. and Macchi, G. (2011) Nutritional condition of 19 Argentine anchovy Engraulis anchoita larvae in connection with nursery grounds properties.

$20 \quad$ Fisheries Research 109, 330-341.

21 Dingsor, G.E., Cianelli, L., Chan, K.S., Ottersen, G. and Stenset, N.C. (2007) Density 22 dependence and density independence during the early life stages of four marine fish stocks. 23 Ecology 88(3), 625-634. 
1 Duffy-Anderson, J.T. and Able, G. (1999) Effects of municipal piers on the growth of

2 juvenile fishes in the Hudson river estuary: a study across pier edge. Marine Biology 133, 3 409-418.

4 Duncan, K. and Holland, K. (2006) Habitat use, growth rates and dispersal patterns of 5 juvenile scalloped hammerhead sharks Sphyrna lewini in a nursery habitat. Marine Ecology 6 Progress Series 312, 211-221.

7 Elliott, M. and Dewailly, F. (1995) The structure and components of European estuarine fish 8 assemblages. Netherlands Journal of Aquatic Ecology 29, 397-417.

9 Elliott, M. and Taylor, C.J.L. (1989) The production ecology of the subtidal benthos of the 10 Forth Estuary, Scotland. Scientia Marina 53, 531-541.

11 Elliott, M., Whitfield, A.K., Potter, I.C., Blaber, S.J.M., Cyrus, D.P., Nordlie, F.G. and 12 Harrison, T.D. (2007) The guild approach to categorizing estuarine fish assemblages: a global 13 review. Fish and Fisheries 8, 241-268.

14 Ellis, T. and Gibson, R.N. (1995) Size-selective predation of O-group flatfishes on a Scottish 15 nursery ground. Marine Ecology Progress Series 127, 27-37.

16 Fodrie, F.J. and Mendoza, G. (2006) Availability, usage and expected contribution of 17 potential nursery habitats for the California halibut. Estuarine Coastal and Shelf Science $6 \mathbf{8}$, $18 \quad 149-164$.

19 Fodrie, F.J., Levin, L. and Lucas, A. (2009) Use of population fitness to evaluate the nursery 20 function of juvenile habitats. Marine Ecology Progress Series 385, 39-49.

21 Fonds, M. (1975). The influence of temperature and salinity on growth of young sole Solea 22 solea L. $10^{\text {th }}$ European Symposium on Marine Biology 1, 109-125.

23 Fonds, M. (1979) Laboratory observations on the influence of temperature and salinity on 24 development of the eggs and growth of the larvae of Solea solea. Marine Ecology Progress 25 Series 1, 91-99. 
1 Fonds, M. and Saksena, V.P. (1977) The daily food intake of young soles (Solea solea, L.) on

2 relation to their size and the water temperature. Actes de Colloques du Centre National pour

3 l'Exploitation des Océans. Nantes, France 4, 51-58.

4 Fonds, M., Cronie, R., Vethaak, A.D. and Van der Puyl, P. (1992) Metabolism, food

5 consumption and growth of plaice (Pleuronectes platessa) and flounder (Platichthys flesus) in

6 relation to fish size and temperature. Netherlands Journal of Sea Research 29, 127-143.

7 Fonds, M., Drinkwaard, B., Resink, J.W., Eysink, G.G.J. and Toet, W. (1989) Measurements

8 of metabolism, food intake and growth of Solea solea (L.) fed with mussel meat or with dry

9 food. In: Aquaculture - A biotechnology in progress (eds N. De Pauw, E. Jaspers, H.

10 Ackefors, and N. Wilkins). European Aquaculture Society, Bredene, Belgium, pp. 851-874.

11 Fonseca, V., Neill, W., Miller, J. and Cabral, H. (2010) Ecophys.Fish perspectives on growth

12 of juvenile soles, Solea solea and Solea senegalensis, in the Tagus estuary, Portugal. Journal

13 of Sea Research 64, 118-124.

14 Fonseca, V., Vinagre, C. and Cabral, H. (2006) Growth variability of juvenile soles Solea

15 solea and Solea senegalenses, and comparison with RNA: DNA ratios in the Tagus estuary;

16 Portugal. Journal of Fish Biology 68, 1551-1562.

17 Franco, A., Elliott, M., Franzoi, P. and Torricelli, P. (2008) Life strategies of fishes in

18 European estuaries: the functional guild approach. Marine Ecology Progress Series 354, 21919228.

20 Freitas, V., Kooijman, S., van der Veer, H. (20012) Latitudinal trends in habitat quality of 21 shallow water flatfish nurseries. Marine Ecology Progress Series 471, 203-214.

22 Friedland, K.D., Ahrenholz, D.W. and Guthrie, J.F. (1996) Formation and seasonal evolution 23 of atlantic menhaden juvenile nurseries in coastal Estuaries. Estuaries and Coasts 19(1), 10524114. 
1 Fujii, T. and Noguchi, M. (1995) Interactions between released and wild Japanese flounder

2 (Paralichthys olivaceus) on a nursery ground. Proceedings of the twenty second US-Japan

3 aquaculture panel symposium. (eds M.R. Collie and J.P. McVey),, United States Japan

4 Cooperation Technical Report 22, 57-65.

5 Fulford, R.S., Peterson, M.S and Grammer, P.O. (2011) An ecological model of the habitat

6 mosaic in estuarine nursery areas: Part I-Interaction of dispersal theory and habitat variability

7 in describing juvenile fish distributions. Ecological Modelling 222, 3203-3215.

8 Gallego, A., North, E. and Houde, E.D. (2012) Understanding and quantifying mortality in

9 pelagic, early life stages of marine organisms - Old challenges and new perspectives. Journal

10 of Marine Systems 93, 1-3.

11 Geange, S. and Stier, A.C. (2009) Order of arrival affects competition in two reef fishes.

12 Ecology 90, 2868-2878.

13 Geffen, A., Van der Veer, H. and Nash, R. (2007) The cost of metamorphosis in flatfishes.

14 Journal of Sea Research 58, 35-45.

15 Geffen, A.J., Nash, R.D.M., Dau, K., Harwood, A.J.P. (2011) Sub-cohort dynamics of 0-

16 group plaice, Pleuronectes platessa L., in the Northern Irish Sea: Settlement, growth and

17 mortality. Journal of Experimental Marine Biology and Ecology, 400, 108-119.

18 Gell, F.R. and Roberts, C.M. (2003) Benefits beyond boundaries: the fishery effects of marine

19 reserves. Trends in Ecology and Evolution 18, 448-455.

20 Gibson, R.N. (1994) Impact of habitat quality and quantity on the recruitment of juvenile

21 flatfishes. Netherlands Journal of Sea Research 32, 191-206.

22 Gibson, R.N. and Robb, L. (1996) Piscine predation on juvenile fishes on a Scottish sandy

23 beach. Journal of Fish Biology 49, 120-138. 
1 Gibson, R.N., Yin, M.C. and Robb, L. (1995) The behavioural basis of predator-prey size

2 relationships between shrimp (Crangon crangon) and juvenile plaice (Pleuronectes platessa).

3 Journal of the Marine Biological Association UK 57, 337-349

4 Gilliers, C., Amara, R., Bergeron, J. and Le Pape, O. (2004) Comparison of growth and

5 condition indices of juvenile flatfish in different coastal nursery grounds. Environmental

6 Biology of Fishes 71, 189-198.

7 Gilliers, C., Le Pape, O., Désaunay, Y., Bergeron, J.P., Schreiber, N., Guérault, D. and

8 Amara, R. (2006) Growth and condition of juvenile sole (Solea solea L.) as indicators of

9 habitat quality in coastal and estuarine nurseries in the Bay of Biscay with a focus on sites

10 exposed to the Erika oil spill. Scientia Marina 70S1, 183-192.

11 Gislason, H., Daan, N., Rice, J.C. and Pope, J.G. (2010) Size, growth, temperature and the

12 natural mortality of marine fish. Fish and Fisheries 11, 149-158.

13 Goto, D. and Wallace, W. (2010) Bioenergetic responses of a forage fish (Fundulus

14 heteroclitus) to habitat degradation and altered prey commubity in polluted salt marshes.

15 Canadian Journal Fisheries and Aquatic Sciences 67, 1566-1584.

16 Goto, T. (2006) Stock size fluctuations and recruitment characteristics of Japanese flounder

17 Paralichthys olivaceus in the coastal waters off Iwate Prefecture Pacific coast of northern

18 Honshu, Japan. Nippon Suisan Gakaishi 72(5), 839-849.

19 Grover, J.J., Buckley, T.W. and Woodbury, D. (2002) Effects of the 1997-1998 El Niño on

20 early-juvenile Pacific hake Merluccius productus: age, growth, abundance, and diet in coastal 21 nursery habitats. Marine Ecology Progress Series 240, 235-247.

22 Guindon, K.Y. and Miller, J.M. (1995) Growth potential of juvenile southern flounder, 23 Paralichthys lethostigma, in low salinity nursery areas of Pamlico Sound, North Carolina, 24 USA. Netherlands Journal of Sea Research 34(1-3), 89-100. 
1 Guisan, A. and Zimmermann, N.E. (2000) Predictive habitat distribution models in ecology.

$2 \quad$ Ecological Modelling 135, 147-186.

3 Hall, S.J. (1998) The effects of fishing on marine ecosystems and communities. Blackwell

4 Science, Oxford.

5 Halpin, P.M. (2000) Habitat use by an intertidal salt-marsh fish: trade offs between predation

6 and growth. Marine Ecology Progress Series 198, 203-214.

7 Hamerlynck, O., Janssen, C.R. and Landtschoote, E. (1989) Fasting and feeding in late larval

8 and early post-larval plaice (Pleuronectes platessa L.). Report of the International Council for

9 the Exploration of the Sea 191: 465.

10 Hampel, H., Cattrijsse, A. and Elliott, M. (2005) Feeding habits of young predatory fishes in

11 marsh creeks situated along the salinity gradients of the Shelde estuary, Belgium, The

12 Netherlands. Helgoland Marine Research 59, 151-162.

13 Harding, D. and Talbot J.W. (1973) Recent studies on the eggs and larvae of the plaice

14 (Pleuronectes platessa L.) in the Southern Bight. Rapport de Procès Verbal du Conseil

15 International pour l'Exploration de la mer 164, 261-269.

16 Hayes, D., Jones, M., Lester, N., Chu, C., Doka, S., Netto, J., Stockwell, J., Thompson, B.,

17 Minns, C., Shuter, B. and Collins, N. (2009) Linking fish population dynamics to habitat

18 conditions: insights from the application of a process-orienter appoach to several Great lakes

19 species. Reviews of Fish Biology and Fisheries 19, 295-312.

20 Hayes, D.B., Ferreri, C.P. and Taylor, W.W. (1996) Linking fish habitat to their recruitment

21 dynamics. Canadian Journal of Fisheries and Aquaculture Science 53, 383-390.

22 Hixon, M. and Jones, G. (2005) Competition, predation and density-dependent mortality in

23 demersal marine fishes. Ecology 86, 2847-2859.

24 Hjort, J. (1914) Fluctuations in the year classes of important food fishes. ICES Journal of 25 Marine Science 1, 5-38. 
1 Hodgson, J., Moilanen, A., Wintle, B. and Thomas, C. (2011) Habitat area, quality and

2 connectivity: striking the balance for efficient conservation. Journal of Applied Ecology 48,

$3 \quad 148-152$.

4 Holbrook, S.J., Forrester, G.E. and Schmitt, R.J. (2000) Spatial patterns in abundance of a

5 damselfish reflect availability of suitable habitat. Oecologia 122,109-120.

6 Houde, E. (2008) Emerging from Hjort's shadow. Journal of Northwest Atlantic Fishery

$7 \quad$ Science 41, 53-70.

8 Houde, E.D. (1987) Fish early life dynamics and recruitment variability. American Fisheries

9 Society Symposium 2, 17-29.

10 Houde, E.D. (1997) Patterns and consequences of selective processes in teleost early life

11 histories. Early life history and recruitment in fish populations (eds R.C. Chambers and E.A.

12 Trippel). Chapman and Hall, New York.

13 Houde, E.D. (2002) Mortality. In: The unique contributions of early life stages. Fishery

14 science (eds L.A. Fuiman and R.G. Werner), Blackwell Publishing, Oxford, pp. 64-87.

15 Hovenkamp, F. (1992) Growth dependent mortality of larval plaice Pleuronectes platessa in 16 the North Sea. Marine Ecology Progress Series 82, 95-101.

17 Howell, P.T., Molnar, D.R. and Harris, R.B. (1999) Juvenile winter flounder distribution by 18 habitat type. Estuaries 22, 1090-1095.

19 Hutchings, J.A. and Jones, M.E.B. (1998) Life history variation and growth rate thresholds for 20 maturity in Atlantic salmon, Salmo salar. Canadian Journal of Fisheries and Aquatic 21 Sciences 55(Suppl. 1), 22-47.

22 Iles, T. (1994) A review of stock-recruitment relationships with reference to flatfish 23 populations. Netherlands Journal of Sea Research 32(3-4), 399-420.

24 Iles, T.C. and Beverton, J.H. (2000) The concentration hypothesis: the statistical evidence. 25 ICES Journal of Marine Science 57, 216-227. 
1 Islam, M.S. and Tanaka, M. (2005) Nutritional condition, starvation status and growth of early

2 juvenile Japanese sea bass (Lateolabrax japonicus) related to prey distribution and feeding in

3 the nursery ground. Journal of Experimental Marine Biology and Ecology 323(2), 172-183.

4 Iwata, S., Fujioka, K., Fukuda, H., and Takeuchi, Y. (2012) Reconsideration of natural

5 mortality of age 0 Pacific bluefin tuna and its variability relative to fish size. Working paper

6 of the ISC Pacific Bluefin Tuna Working Group Meeting, 31 January-7 February 2012, La

7 Jolla, California, USA. ISC/12/PBFWG1/13.

8 Johnson, DW. (2007) Habitat complexity modifies post-settlement mortality and recruitment

9 dynamics of marine fish. Ecology 88, 1716-1725.

10 Johnson, A., Jenkins, S., Hiddink, J. and Hinz, H. (2013) Linking temperate demersal fish

11 species to habitat: scales, patterns and future directions. Fish and Fisheries 14(3), 256-80.

12 Jones, R.F., Baltz, D.M. and Allen, R.L. (2002) Patterns of resource use by fishes and 13 macroinvertebrates in Barataria Bay, Louisiana. Marine Ecology Progress Series 237, 27114289.

15 Juanes, F. (2007) Role of habitat in mediating mortality during the post-settlement transition 16 phase of temperate marine fishes. Journal of Fish Biology 70, 661-677.

17 Kaplan, D.M. (2009) Fish life histories and marine protected areas: an odd couple? Marine 18 Ecology Progress Series 377, 213-225.

19 Karakiri, M., Berghahn, R. and Von Westernhagen, H. (1989) Growth differences in 0-group 20 plaice Pleuronectes platessa as revealed by otolith microstructure analysis. Marine Ecology 21 Progress Series 55, 15-22.

22 Klanjscek, T., Caswell, H., Neubert, M.G. and Nisbet, R.M. (2006) Integrating dynamic 23 energy budgets into matrix population models. Ecological Modelling 196, 407-420.

24 Kooijman, S.A.L.M. (2000) Dynamic Energy and Mass Budgets in Biological Systems. 25 Cambridge University Press, Great Britain. Second Edition. 
1 Kostecki, C., Le Loc'h, F., Roussel, J.M., Desroy, N., Huteau, D., Le Bris, H. and Le Pape, O.

2 (2010) Dynamics of an estuarine nursery ground: the spatio-temporal relationship between the

3 river flow and the food web of the juvenile common sole (Solea solea) as revealed by stable

4 isotopes analysis. Journal of Sea Research 64, 54-60.

5 Kostecki, C., Rochette, S., Girardin, R., Blanchard, M., Desroy, N. and Le Pape, O. (2011)

6 Reduction of flatfishes habitat as a consequence of the proliferation of an invasive mollusc.

7 Estuarine, Coastal and Shelf Science 92, 154-160.

8 Kostecki, C., Roussel, J.M., Desroy, N., Roussel, G., Lanshere, J., Le Bris, H. and Le Pape,

9 O. (2012). The main influence of microphytobenthos on juvenile flatfish food web in a 10 macrotidal nursery Bay. Marine Ecology Progress Series 449: 221-232.

11 Koutsikopoulos, C., Desaunay, Y., Dorel, D. and Marchand, J. (1989) The role of coastal

12 areas in the life history of sole (Solea solea L.) in the Bay of Biscay. Scientia marina 53, 56713575.

14 Koutsikopoulos, C., Fortier, L. and Gagne, J.A. (1991) Cross-well dispersion of dover sole 15 (Solea solea (L.)) eggs and larvae in Biscay Bay and recruitment to inshore nurseries. 16 Journal of plankton research 13, 923-945.

17 Laegdsgaard, P. and Johnson, C. (2001) Why do juvenile fish utilise mangrove habitats. 18 Journal of Experimental Marine Biology and Ecology 257, 229-253.

19 Lafaille, P., Feunteun, E. and Lefeuvre, J.C. (2000) Composition of fish communities in a 20 European macrotidal salt marsh (the Mont Saint Michel Bay, rance). Estuarine, Coastal and $21 \quad$ Shelf Science 51, 429-438.

22 Laffargue, P., Lagardère, F. Rijnsdorp, A.D., Fillon, A. and Amara, R. (2007) Growth 23 performances of juvenile sole Solea solea under environmental constraints of embayed 24 nursery areas. Aquatic Living Resources 20, 213-221. 
1 Lamberth, S., Drapeau, L. and Branch, G.M. (2009) The effects of altered freshwater inflows

2 on catch rates of non estuarine dependent fish in multispecies nearshore fisheries. Estuarine,

3 Coastal and Shelf Science 84, 527-538.

4 Le Pape, O., Holley, J., Guérault, D. and Désaunay, Y. (2003a) Quality of coastal and 5 estuarine essential fish habitat: estimations based on the size of juvenile common sole (Solea 6 solea L.). Estuarine, Coastal and Shelf Science 58, 793-803.

7 Le Pape, O., Chauvet, F., Mahévas, S., Lazure, L., Guérault, G. and Désaunay, Y. (2003b)

8 Quantitative description of habitat suitability for the juvenile common sole (Solea solea, L.)

9 and contribution of different habitats to the adult population in the Bay of Biscay (France).

10 Journal of Sea Research 50(2-3), 139-149.

11 Le Pape, O., Chauvet, F., Désaunay, Y. and Guérault, G. (2003c) Relationship between 12 interannual variations of the river plume and the extent of nursery grounds for the common 13 sole (Solea solea, L.) in Vilaine Bay. Effects on recruitment variability. Journal of Sea 14 Research 50(2-3), 177-185.

15 Le Pape, O., Désaunay, Y. and Guérault, D. (2003d) Relationship between fluvial discharge 16 and sole (Solea solea, L.) recruitment in the Bay of Biscay (France). Study of an estuarine 17 nursery ground and application on a stock scale. ICES Marine Science Symposia 219, 241$18 \quad 248$.

19 Le Pape, O., Baulier, L., Cloarec, A., Martin, J., Le Loc'h, F. and Désaunay, Y. (2007) Habitat 20 suitability for juvenile common sole (Solea solea, L.) in the Bay of Biscay (France): A 21 quantitative description using indicators based on epibenthic fauna. Journal of Sea Research $2257,126-136$.

23 Le Pape, O., Modéran, J., Beaunée, G., Riera, P., Nicolas, D., Savoye, N., Harmelin-Vivien, 24 M., Darnaude, A., Brind'Amour, A., Le Bris, H., Cabral, H., Vinagre, C., França, S. and 25 Kostecki, C. (2013) Organic matter sources for flatfish juveniles in coastal and estuarine 
1 nursery grounds: a meta-analysis for the common sole (Solea solea) in contrasted systems of

2 Western Europe. Journal of Sea research 75, 85-95.

3 Leakey, C.D.B., Atrill, M.A., Jennings, S. and Fitzsimons, M.F. (2008) Stable isotopes in

4 juvenile marine fishes and their invertebrate prey from the Thames estuary, UK, and adjacent

5 coastal regions. Estuarine, Coastal and Shelf Science 77, 513-522.

6 Leakey, C.D.B., Atrill, M.A., Jennings, S. and Fitzsimons, M.F. (2008) Stable isotopes in

7 juvenile marine fishes and their invertebrate prey from the Thames estuary, UK, and adjacent

8 coastal regions. Estuarine, Coastal and Shelf Science 77, 513-522.

9 Lekve, K., Ottersen, G., Stenseth, N.C. and Gjosaetter, J. (2002) Length dynamics in juvenile

10 coastal skagerrak cod: effects of biotic and abiotic processes. Ecology 86, 1676-1688.

11 Levin, P., Petrik, R. and Malone, J. (1997) Interactive effects of habitat selection, food supply

12 and predation on recruitment of an estuarine fish. Oecologia 112, 55-63.

13 Levin, P.S. and Stunz, G.W. (2005) Habitat triage for exploited fishes: can we identify

14 essential fish habitat? Estuarine, Coastal and Shelf Science 64, 70-78.

15 Lewis, D.B. (2001) Trade-offs between growth and survival responses of freshwater snails to 16 predacious crayfish. Ecology 82, 758-765.

17 López-Rasgado, F.J., Herzka, S.Z. (2009) Assessment of habitat quality for juvenile 18 California halibut (Paralichthys californicus) in a seasonally arid estuary. Fishery Bulletin $19 \quad \mathbf{1 0 7}, 343-358$.

20 Malloy, K.D., Yamashita, Y., Yamada, H., Targett, T.E. (1996) Spatial and temporal patterns 21 of juvenile stone flounder Kareius bicoloratus growth rates during and after settlement. 22 Marine Ecology Progress Series 131, 49-59.

23 Manderson, J.P., Phelan, B.A., Stoner, A.W. and Hilbert, J. (2000) Predator prey relations 24 between age-1+ summer flounder (Paralichthys dentatus, L.) and age 0 winter flounder 
1 (Pseudopleuronectes americanus, Walbaum): predator diets, prey selection, and effects of

2 sediments and macrophytes. Journal of Experimental Marine Biology Ecology 251, 17-39.

3 Marchand, J. (1993) The influence of seasonal salinity and turbidity maximum variations on

4 the nursery function of the Loire estuary (France). Netherlands Journal of Aquatic Ecology

$5 \quad 27,427-436$.

6 Marchand, J. and Masson, G. (1989) Process of estuarine colonization by 0-groupsole (Solea

7 solea): hydrological conditions, behaviour and feeding activity in the Vilaine estuary.

8 Rapport de Procès Verbal de la Réunion du Conseil International pour l'Exploration de la

9 Mer 191, 287-295.

10 Marchand, J., Tanguy, A., Laroche, J., Quiniou, L. and Morales, D. (2003) Responses of

11 European flounder Platichthys flesus populations to contaminant in different estuaries along

12 Atlantic coast of France. Marine Ecology Progress Series 260, 273-284.

13 McConnaughey, R.A. and Smith, K.R. (2000) Associations between flatfish abundance and

14 surficial sediments in the eastern Bering Sea. Canadian Journal of Fishery and Aquatic

15 Sciences 57, 2410-2419.

16 McCormick, M.I. and Molony, B. (1993) Quality of the tropical reef fish, Upeneus tragula

17 (family: Mullidae), at settlement: Is size a good indicator of condition? Marine Ecology

18 Progress Series 98, 45-54.

19 McErlean, A.J., O'Connor, S.G., Mihursky, J.A. and Gibson, C.I. (1973) Abundance, diversity

20 and seasonnal patterns of estuarine fish populations. Estuarine and Coastal Marine Science 1,

$21 \quad 19-36$.

22 McLusky, D.S. and Elliott, M. (2004) The Estuarine Ecosystem; ecology, threats and 23 management, 3rd Edn. Oxford University Press, Oxford. 
1 Megrey, B.A., Rose, K.A., Klumb, R.A., Hay, D.E., Werner, F.E., Eslinger, D.L. and Smith,

2 S.L. (2007) A bioenergetlics-based population dynamics model of Pacific herring (Clupea

3 harengus pallasi) coupled to a lower trophic level nutrient-phytoplankton-zooplankton model:

4 Meng, L. and Cicchetti, G. (2005) Relationships between juvenile winter flounder and

5 multiple scale habitat variation in Narraganset Bay, Rhode Island. Transactions of the

6 American Fisheries 134, 1509-1519.

7 Meng, L., Gray, C., Talpin, B. and Kupcha, E. (2000) Using winter flounder growth rates to

8 assess habitat quality in Rhode Islands coastal lagoons. Marine Ecology Progress Series 201,

$9287-299$.

10 Meng, L., Orphanides, C.D. and Powell, J.C. (2002) Use of fish index to assess habitat quality

11 in Narragansett Bay, Rhode Island. Transactions of the American Fisheries Society 131, 73112742.

13 Mesnildrey L., Gascuel D. and Le Pape O. (2013) Marine Protected Areas and fisheries 14 management: some criteria for ecological efficiency. Aquatic living resources 26, 159-170.

15 Meyer, S., Caldarone, E.M., Chicharo, M.A., Clemmesen, C., Faria, A.M., Faulk, C., 16 Folkvord, A., Holt, G.J., Hoie, H., Kanstinger, P., Malzahn, A., Moran, D., Petereit, C., 17 Stottrup, J.G. and Peck, M.A. (2012) On the edge of death: Rates of decline and lower 18 threshholds of biogeochemical condition in food-deprived fish larvae and juveniles. Journal 19 of Marine Systems 93, 11-24.

20 Miller, J.M., Reed, J.P. and Pietrafesa, L.J. (1984) Patterns, mechanisms and approaches to 21 the study of migrations of estuarine dependent fish larvae and juveniles. In: Mechanisms of 22 migration in fishes (eds J.D. McCleave, G.P. Arnold, J.J. Dodson and W.H. Neill). Plenum 23 Press, New York. pp 209-225. 
1 Miller, T.J., Crowder, L.B., Rices, J.A. and Marshall, E.A. (1988) Larval size and recruitment

2 mechanisms in fishes: Toward a conceptual framework. Canadian Journal of Fisheries and

3 aquaculture Sciences 45, 1657-1667.

4 Minto, C., Myers, R.A. and Blanchard, W. (2008) Survival variability and population density

5 in fish populations. Nature 452, 344-348.

6 Moore, D.M. (1978) Seasonal changes in distribution of intertidal macrofauna in the lower

7 Mersey Estuary, U.K. Estuarine and Coastal Marine Science 7, 117-125.

8 Nash, R.D.M. and Geffen, A.J. (2000) The influence of nursery grounds processes in the

9 determination of year-class strength in juvenile plaice Pleuronectes platessa L. in Port Erin

10 Bay, Irish Sea. Journal of Sea Research 44, 101-110.

11 Nash, R.D.M. and Geffen, A.J. (2012) Mortality through the early life-history of fish: What

12 can we learn from European Plaice (Pleuronectes platessa L.)? Journal of Marine Systems 93, $13 \quad 58-68$.

14 Nash, R.D.M., Geffen, A.J, Burrows, M.T. and Gibson, R.N. (2007) Dynamics of shallow-

15 water juvenile flatfish nursery grounds: application of the shelf-thinning rule. Marine Ecology

16 Progress Series 344, 231-244.

17 Nicolas D., Lobry, J., Le Pape, O. and Boët, P. (2010) Functional diversity in European

18 estuaries: Relating the composition of fish assemblages to the abiotic environment. Estuarine,

19 Coastal and Shelf Science 88, 9-338.

20 Nicolas, D., Le Loc'h, F., Desaunay, Y., Hamon, D., Blanchet, A. and Le Pape, O. (2007)

21 Relationship between benthic macrofauna and habitat suitability for juvenile common sole

22 (Solea solea, L.) in the Vilaine estuary (Bay of Biscay, France) nursery ground. Estuarine

23 Coastal and Shelf Science 73, 639-650.

24 Norcross, B.L., Blanchard, A. and Holladay, B.A. (1999) Comparison of models for defining

25 nearshore flatfish nursery areas in Alaskan waters. Fisheries Oceanography 8, 50-67. 
1 Norcross, B.L., Muter, F.J. and Holladay, B. (1997) Habitat models for juvenile pleuronectids

2 around Kodiak Island, Alaska. Fishery Bulletin 95, 504-520.

3 Nunn, A., Tewson, L., Cow X. (2012) The foraging ecology of larval and juvenile fishes.

4 Review in Fish Biology and Fisheries 22, 377-408.

5 Ohlberger, J., Otero, J., Edeline, E., Winfield, I.J., Stenseth, N.C. and Vollestad, L.A. (2012)

6 Biotic and abiotic effects on cohort size distributions in fish. Oikos 1226):835-44.

7 Pappal, A.L., MacDonald, D.G. and Rountree, R.A. (2009) Evidence of cobble habitat

8 preference in age-0 winter flounder, Pseudopleuronectes americanus. Marine and Freshwater

9 Behaviour and Physiology, 42, 43-53.

10 Parrish, F.A., DeMartini, E.E. and Ellis, D. (1997) Nursery habitat in relation to production of 11 juvenile snapper Pristipomoides filamentosus in the Hawaian Archipelago. Fisheries Bulletin $1295,137-149$.

13 Pasquaud, S., David, V., Lobry, J., Girardin, M., Sautour, B. and Elie, P. (2010) Exploitation

14 of trophic resources by fish under stressful estuarine conditions. Marine Ecology Progress 15 Series 400, 207-219.

16 Pasquaud, S., Elie, P., Jeantet, C., Billy, I., Martinez, P. and Girardin, M. (2008) A 17 preliminary investigation of the fish food web in the Gironde estuary, France, using dietary 18 and stable isotope analyses. Estuarine Coastal and Shelf Science 78, 267-279.

19 Pasquaud, S., Pillet, M., David, V., Sautour, B. and Elie, P. (2010) Determination of fish 20 trophic levels in an estuarine system. Estuarine, Coastal and Shelf Science 86, 237-246.

21 Pearcy, W.G. (1962a) Ecology of an estuarine population of winter flounder, 22 Pseudopleuronectes americanus (Walbaum). II. Distribution and dynamics of larvae. Bulletin 23 of the Bingham Oceanographic Collection 18,16-37.

24 Pearcy, WG (1962b) Ecology of an estuarine population of winter flounder, 25 Pseudopleuronectes americanus (Walbaum). III. Distribution, abundance, growth, and 
1 production of juveniles, survival of larvae and juveniles. Bulletin of the Bingham

2 Oceanographic Collection 18, 39-64.

3 Pelletier, D. and Magal, P. (1996) Dynamics of a migratory population under different fishing

4 effort allocation schemes in time and space. Canadian Journal of Fisheries and Aquatic

5 Sciences 53, 1186-1199.

6 Peterman, R., Bradford, M., Lo, N.C.H. and Methot, R.D. (1988) Contribution of early life

7 stages to interannual variability in recruitment of Northern Anchovy. Canadian Journal of

$8 \quad$ Fisheries and Aquatic Sciences 45, 8-16.

9 Peterson, C.H., Summerson, H.C., Thomson, E., Lenihan, H.S., Grabowski, J., Manning, L.,

10 Micheli, F. and Johnson, G. (2000) Synthesis of linkages between benthic and fish

11 communities as key to protecting essential fish habitat. Bulletin of Marine Science 66, 75912774.

13 Peterson, M. (2003) A conceptual view of environment-habitat-production linkages in tidal 14 river estuaries. Reviews in Fisheries science 11, 291-313.

15 Phelan, B.A., Goldberg, R., Bejda, A.J., Pereira, J., Hagan, S., Clark, P., Studholme, A.L., 16 Calabrese, A. and Able K.W. (2000) estuarine and habitat related differences in growth rates 17 of young of the year winter flounder (Pseudopleuronectes americanus) and tautog (Tautoga 18 onitis) in three northeastern US estuaries. Journal of Experimental Marine Biology and 19 Ecology 247, 1-28.

20 Phelan, B.A., Manderson, J.P., Stoner, A.W. and Bejda, A.J. (2001) Size-related shifts in the 21 habitat associations of young-of-the-year winter flounder (Pseudopleuronectes americanus):

22 field observations and laboratory experiments with sediments and prey. Journal of 23 Experimental Marine Biology and Ecology 257, 297-315. 
1 Pihl, L., Modin, J. and Wennhage, H. (2000) Spatial distribution patterns of newly settled

2 plaice (Pleuronectes platessa L.) along the Swedish Skagerrak archipelago. Journal of Sea

3 Research 44, 65-80.

4 Polacheck, T., Hearn, W.S., Miller, C., Whitelaw, W., and Stanley, C. (1997) Updated

5 estimates of mortality rates for juvenile SBT from multi $\square$ year tagging of cohorts.

6 CCSBTSC/9707/26.

7 Rauck, G. and Zijlstra, J.J. (1978) On the nursery-aspects of the Wadden sea for some

8 commercial fish species and possible long term changes. Rapport de Procès Verbal de la

9 Réunion Annuelle du Conseil International pour l'Exploration de la Mer 172, 266-275.

10 Rijnsdorp, A.D., Van, B.F.A, Flatman, S, Millner, R.M., Riley, J.D, Giret, M. and De Clerck,

11 R. (1992) Recruitment of sole stocks, Solea solea (L.), in the northeast Atlantic. Netherlands

12 Journal of Sea Research 29, 173-192.

13 Riley, J.D., Symonds, D.J. and Woolner, L. (1981) On the factors influencing the distribution

14 of 0-group demersal fish in coastal waters. Rapport de Procès Verbal de la Réunion Annuelle

$15 d u$ Conseil International pour l'Exploration de la Mer 178, 223-228.

16 Riou, P., Le Pape, O. and Rogers, S.I. (2001) Relative contributions of different sole and

17 plaice nurseries to the adult population in the Eastern Channel: application of a combined

18 method using generalized linear models and a geographic information system. Aquatic Living

19 Resources 14, 125-135.

20 Rochette, S., Huret, M., Rivot, E and Le Pape, O. (2012) Coupling hydrodynamic and

21 individual-based transport models to simulate long-term larval supply on coastal nursery area.

22 Fisheries and oceanography 21, 229-242.

23 Rochette, S., Le Pape, O., Vigneau, J. and Rivot, E. (2013) A bayesian state-space model

24 approach to integrate the whole life cycle in marine fish population model. Ecological 25 applications 23, 1659-1676. 
1 Rochette, S., Rivot, E., Morin, J., Mackinson, S., Riou, P. and Le Pape, O. (2010) Effect of

2 nursery habitat degradation on flatfish population: Application to Solea solea in the Eastern

3 Channel (Western Europe). Journal of Sea Research 64, 34-44.

4 Rogers, S.I. (1992) Environmental factors affecting the distribution of sole (Solea solea (L.))

5 within a nursery area. Netherlands Journal of Sea Research 29, 153-161.

6 Rogers, S.I. (1994) Populations density and growth rate juvenile sole Solea solea (L.).

$7 \quad$ Netherlands Journal of Sea Research 32, 353-360.

8 Rooper, C., Gunderson, D. and Armstrong, D. (2004) Application of the concentration

9 hypothesis to English sole in nursery estuaries and potential contribution to coastal fisheries.

10 Estuaries 27, 102-111.

11 Rose, K.A., Tyler, J.A., Chambers, R.C., Klein-MacPhee, G. and Danila, D.J. (1996)

12 Simulating winter flounder population dynamics using coupled individual-based young-of-

13 the-year and age-structured adult models. Canadian Journal of Fisheries and Aquatic

14 Sciences, 53, 1071-1091.

15 Ross, S. (2003) The relative value of different estuarine nursery areas in North Carolina for

16 transcient juvenie marine fishs. Fishery bulletin 101, 384-404.

17 Rotenberry, J., Preston, K. and Knick, S. (2006) GIS-based niche modeling for mapping 18 species habitat. Ecology 87, 1458-1464.

19 Ruiz, J., Gonzalez-Quiros, R., Prieto, L. and Navarro, G. (2009) A Bayesian model for 20 anchovy (Engraulis encrasicolus): the combined forcing of man and environment. Fisheries 21 oceanography $18,62-76$.

22 Salen-Picard, C., Darnaude, A.M., Arlhac, D. and Harmelin-Vivien, M.L. (2002) Fluctuations 23 of macrobenthic populations: a link between climate-driven run-off and sole fishery yields in 24 the Gulf of Lions. Oecologia 133, 380-388. 
1 Salgado, J.P., Cabral, H.N. and Costa, M.J. (2004) Feeding ecology of the gobies

2 Pomatoschistus minutes (Pallas, 1770) and Pomatoschistus microps (Kroyer, 1838) in the

3 upper Tagus estuary, Portugal. Scientia Marina 68, 425-434.

4 Scharf, F. (2000) Patterns in abundance, Growth, and Mortality of Juvenile red drum across

5 estuaries on the Texas coast with Implications for recruitment and stock enhancement.

6 Transactions of the American Fisheries Society 129, 1207-1222.

7 Schmitt, R.J. and Holbrook, S.J. (2000) Habitat-limited recruitment of coral reef damselfish.

$8 \quad$ Ecology 81, 3479-3494.

9 Searcy, S.P., Eggleston, D.B. and Hare, J.A. (2007) Is growth a reliable indicator of habitat

10 quality and essential fish habitat for a juvenile estuarine fish? Canadian Journal of Fisheries

11 and Aquaculture Science 64, 681-691.

12 Selleslagh, J. (2008) Fonctionnement des nourriceries intertidales et estuariennes: influence

13 de l'environnement sur la dynamique et les performances physiologiques de l'ichtyofaune.

14 PhD Thesis, Université du littoral Côte d'Opale, France.

15 Selleslagh, J. and Amara, R. (2008) Environmental factors structuring fish composition and

16 assemblages in a small macrotidal estuary (eastern English Channel). Estuarine, Coastal and

17 Shelf Science 79, 507-517.

18 Selleslagh, J. and Amara, R. (2013) Effect of starvation on condition and growth of juvenile

19 plaice Pleuronectes platessa: nursery habitat quality assessment during the settlement period.

20 Journal of the Marine Biological Association of the United Kingdom 93, 479-488.

21 Selleslagh, J., Lesourd, S. and Amara, R. (2012) Comparison of macrobenthic assemblages of

22 three fish estuarine nurseries and their importance as foraging grounds. Journal of the Marine

23 Biological Association of the United Kingdom 92, 85-97.

24 Sheaves, M. (2009) Consequences of ecological connectivity: the coastal ecosystem mosaic.

25 Marine Ecology Progress Series 391, 107-115. 
1 Shepherd, J.G and Cushing, D.H..(1980) A mechanism for density-dependent survival of

2 larval fish as the basis of a stock-recruitment relationship. ICES Journal of Marine Science

$3 \quad \mathbf{1 8 5}, 255-267$.

4 Shi, Y., Gunderson, D.R. and Sullivan, P.J. (1997) Growth and survival of 0 super (+) English

5 sole, Pleuronectes vetulus, in estuaries and adjacent nearshore waters off Washington. Fishery

$6 \quad$ Bulletin 95, 161-173.

7 Simon, M., Fromentin, J.M., Bonhommeau, S., Gaertner, D., Brodziak, J., Etienne, M.P.

8 (2012) Effects of Stochasticity in Early Life History on Steepness and Population Growth

9 Rate Estimates: An Illustration on Atlantic Bluefin Tuna. PLoS ONE 7(10): e48583.

10 Sinclair, M. (1997) Recruitment in fish populations: the paradigm shift generated by ICES

11 Committee A. In: Early life history and recruitment in fish populations (eds R.C. Chambers

12 and E.A. Trippel). Chapman \& Hall 21, London.

13 Sogard, S.M. (1992) Variability in growth rates of juvenile fishes in different estuarine 14 habitats. Marine Ecology Progress Series 85, 35-53.

15 Sogard, S.M. (1997) Size-selective mortality in the juvenile stage of teleost fishes: a review.

16 Bulletin of Marine Science 60, 1129-1157.

17 Steizenmuller, V., Ellis, J. and Rogers, S. (2010) Towards spatially explicit risk assessment

18 for marine management; assessing the vulnerability of fish to aggregate extraction. Biological

19 Conservation 143, 230-238.

20 Stier, A., Geange, S., Hanson, K., and Bolker, B. (2013) Predator desnity and timing of arrival 21 affect reef community assembly. Ecology 94, 1057-1068.

22 Stoner, A., Spencer, M.L. and Ryer, C.H. (2007) Flatfish-habitat associations in Alaska 23 nursery grounds: Use continuous video records for multiscale spatial analysis. Journal of Sea $24 \quad$ Research 57, 137-151. 
1 Stottrup, J.G. and Sparrevohn, C.R. (2007) Can stock enhancement enhance stocks? Journal 2 of Sea Research 57, 104-113.

3 Stunz, G.W., Minello, T.J. and Levin, P.S. (2002) Growth of newly settled red drum

4 Scianeops ocellatus in different estuarine habitats types. Marine Ecology Progress Series 238, $5 \quad 227-236$.

6 Suthers, I.M. (1998) Bigger? Fatter? Or is faster growth better? Considerations on condition 7 in larval and juvenile coral-reef fish. Australian Journal of Ecology 23, 265-273.

8 Suthers, I.M., Fraser, A. and Fran, K.T. (1992) Comparison of lipid, otolith and morphometric 9 condition indices of pelagic juvenile cod (Gadus morhua) from the Canadian Atlantic. Marine $10 \quad$ Ecology Progress Series 84, 31-40.

11 Swain, D.P. (1993) Age and density dependent bathymetric pattern of Atlantic cod (Gadus 12 morhua) in the Southern Gulf of St Lawrence. Canadian Journal of Fisheries and Aquatic 13 Sciences 50, 1255-1264.

14 Swain, D.P. and Morin, R. (1996) Relationships between geographic distribution and 15 abundance of American plaice (Hippoglossoides platessoides) in the southern Gulf of St.

16 Lawrence. Canadian Journal of Fishery and Aquaculture Sciences 53, 106-119.

17 Talbot, J. W. (1977) The dispersal of plaice eggs and larvae in the Southern Bight of the 18 North Sea. ICES Journal of Marine Science 37, 221-48.

19 Teal, L.R., De Leeuw, J.L, Van der Veer, H.W. and Rijnsdorp, A.D. (2008) Effects of climate 20 change on growth of 0-group sole and plaice. Marine Ecology Progress Series 358, 219-230.

21 Trimoreau, E., Arcambault, B., Brind'Amour, A., Guitton J. and Le Pape O. (in press). 22 Quantitative estimate of the function of soft sheltered productive coastal areas as essential 23 flatfish nursery habitat. Estuarine, Coastal and Shelf Science.

24 Tsuji, S. (1998) Stock status of Southern bluefin tuna. $7^{\text {th }}$ Expert Consultation on Indian 25 Ocean Tunas, Victoria, Seychelles. IOTC Proceedings 1, 219-226. 
1 Van de Wolfshaar, K.E., HilleRisLambers, R. and A. Gårdmark, A. (2011) Effect of habitat

2 productivity and exploitation on populations with complex life cycles. Marine Ecology

3 Progress Series 438, 175-184.

4 Van der Veer, H., Bergham, R., Miller, J. and Rijnsdorp, A. (2000a) Recruitment in flatfish,

5 with special emphasis on North Atlantic species: Progress made by the Flatfish Symposia.

6 ICES Journal of Marine Science 57, 202-215.

7 Van der Veer, H., Freitas, V., Koot, J. and Witte, J.Z.A. (2010) Food limitation in epibenthic

8 species in temperate intertidal systems in summer: analysis of 0-group plaice Pleuronectes

9 platessa. Marine Ecology Progress Series 416, 215-227.

10 Van der Veer, H.K., Dapper, R. and Witte, J.I.J. (2001) The nursery function of the intertidal

11 areas in the western Wadden Sea for 0-group sole Solea solea (L.). Journal of Sea Research

$12 \quad 45,271-279$.

13 Van der Veer, H.W. (1986) Immigration, settlement and density-dependent mortality of a

14 larval and early post-larval 0-group plaice (Pleuronectes platessa) population in the western

15 Dutch Wadden Sea. Marine Ecology Progress Series 29, 223-236.

16 Van der Veer, H.W. and Witte, J.I.J. (1993) The 'maximum growth/optimal food condition'

17 hypothésis: a test for 0-group plaice Pleuronectes platessa in the Dutch Wadden Sea. Marine

18 Ecology Progress Series 10, 81-90.

19 Van der Veer, H.W., Berghahn, R. and Rijnsdorp, A.D. (1994) Impact of juvenile growth on

20 recruitment in flatfish. Netherlands Journal of Sea Research 32, 153-173.

21 Van der Veer, H.W., Ellis, T., Miller, J.M., Pihl, L. and Rijnsdorp, A. (1997) Size-selective

22 predation on juvenile North Sea flatfish and possible implications for recruitment. In: Early

23 life history and recruitment in fish populations (eds R.C. Chambers and E.A. Trippel).

24 Chapman and Hall, New York. 
1 Van der Veer, H.W., Geffen, A. and Witte, J.I.J. (2000b) Exceptionally strong year classes in

2 plaice Pleuronectes platessa: are they generated during the pelagic stage only, or also in the 3 juvenile stage? Marine Ecology Progress Series 199, 255-262.

4 Van der Veer, H.W., Kooijman, S. and Van der Meer, J. (2003) Body size scaling

5 relationships in flatfish as predicted by Dynamic Energy Budgets (DEB theory): implications

6 for recruitment. Journal of Sea Research 50, 255-270.

7 Vasconcelos, R.P., Reis-Santos, P., Costa, M. and Cabral, H.N. (2011) Connectivity between

8 estuaries and marine environment: integrating metrics to assess estuarine nursery function.

$9 \quad$ Ecological indicators 11, 1123-1133.

10 Vasconcelos, R.P., Eggleston, D.E., Le Pape, O., Tulp, I. (in press) Patterns and processes of 11 habitat-specific demographic variability in exploited marine species. ICES Journal of Marine

12 Science.

13 Vinagre, C. and Cabral, H. (2008) Prey consumption by juvenile soles, Solea solea and Solea 14 senegalensis, in the Tagus estuary, Portugal. Estuarine, Coastal and Shelf Science 78, 45-50.

15 Vinagre, C., Fonseca, V., Cabral, H. and Costa, M. (2006) Habitat suitability index models for 16 juvenile soles, Solea solea \& S. senegalensis, in the Tagus estuary: defining variables for 17 species management. Fisheries research 82, 140-149.

18 Vinagre, C., Franca, S., Costa, M.J. and Cabral, H.N. (2005) Niche overlap between 19 flatfishes, Platichthys flesus and Solea solea, in a southern European estuary and adjacent 20 coastal waters. Journal of Applied Fish Biology 21, 114-120.

21 Vinagre, C., Salgado, J., Costa, M. and Cabral, H. (2008) Nursery fidelity, food web 22 interactions and primary sources of nutrition of the juveniles of Solea solea and $S$. 23 senegalensis in the Tagus estuary (Portugal): a stable isotop approach. Estuarine, Coastal and 24 Shelf Science 76, 255-264. 
1 Wahl, D.H. and Stein, R.A. (1989) Comparative vulnerability of three Esocids to largemouth

2 bass. Canadian Journal of Fisheries and Aquatic Sciences 46, 2095-2103.

3 Walsh, S.J. (1996) Life history and ecology of long rough dab Hippoglossoides platessoides

4 (F) in the Barents Sea. Journal of Sea Research 36, 285-310.

5 Wennhage, H. (2000) Vulnerability of settling plaice Pleuronectes platessa to predation:

6 effects of developmental stage and alternative prey. Marine Ecology Progress Series 203, $7 \quad 289-299$.

8 Wennhage, H. and Gibson, R.N. (1998) Influence of food supply and a potential predator

9 (Crangon crangon) on settling behaviour of plaice (Pleuronectes platessa). Journal of Sea

$10 \quad$ Research 39, 103-112.

11 Wennhage, H. and Pihl, L. (2001) Settlement patterns of newly settled plaice (Pleuronectes 12 platessa) in a non tidal Swedish fjord in relation to larval supply and benthic predators. 13 Marine Biology 139, 877-889.

14 Wetz, M., Hutchinson, E., Lunetta, R., Paerl, H. and Taylor, J. (2010). Severe droughts reduce 15 estuarine primary productivity with cascading effects on higher trophic levels. Limnology 16 Oceanography 56, 627-638.

17 White, J.W. and Caselle, J.E. (2008) Scale-dependent changes in the importance of larval 18 supply and habitat to abundance of a reef fish. Ecology 89(5), 1323-1333.

19 Whitlock, R.E., McAllister, M.K and Block, B.A. 2012 Estimating fishing and natural 20 mortality rates for Pacific bluefin tuna (Thunnus orientalis) using electronic tagging data. 21 Fisheries Research 119-120: 115-127.

22 Wouters, N. and Cabral, H.N. (2009) Are flatfish nursery grounds richer in benthic preys. 23 Estuarine, Coastal and shelf science 83, 613-620.

24 Yamashita, Y., Tanaka, M. and Miller, J.M. (2001) Ecophysiology of juvenile flatfish in 25 nursery grounds. Journal of Sea Research 45, 205-218. 
Table 1: Mortality during the pre-adult life phases in some marine fish populations

\begin{tabular}{|c|c|c|c|c|c|}
\hline Species & Populations & $\begin{array}{c}\text { Overall pre-adult } \\
\text { survival* }\end{array}$ & $\begin{array}{l}\text { Eggs \& larvae } \\
\text { surv.* }\end{array}$ & $\begin{array}{l}\text { Juvenile } \\
\text { surv.* }\end{array}$ & Reference \\
\hline Northern anchovy (Engraulis mordax, Engraulidae) & All or whole & $10^{-5}$ & $10^{-3}$ & $10^{-2}$ & Peterman et al. 1988 \\
\hline European anchovy (Engraulis encrasicolus, Engraulidae) & Bay of Biscay & $10^{-5}$ & $10^{-3}$ & $10^{-2}$ & $\begin{array}{l}\text { Calculated from Allain et al. } \\
2003 \text { and Allain } 2004\end{array}$ \\
\hline Altantic cod (Gadus morhua, Gadidae) & North Sea & $10^{-7}-10^{-8}$ & $10^{-5}-10^{-6}$ & $10^{-2}$ & Houde 2002 \\
\hline Common sole (Solea solea, Soleidae) & $\begin{array}{l}\text { Bay of Biscay } \\
\text { Eastern Channel }\end{array}$ & $\begin{array}{l}10^{-5} \\
10^{-5}\end{array}$ & $\begin{array}{l}10^{-3} \\
10^{-3}\end{array}$ & $\begin{array}{l}10^{-2} \\
10^{-2}\end{array}$ & $\begin{array}{l}\text { calculated from Koutsikopoulos } \\
\text { et al. } 1989 \text { \& } 1991 \\
\text { Rochette et al. } 2013 .\end{array}$ \\
\hline Plaice (Pleuronectes platessa, Pleuronectidae) & $\begin{array}{l}\text { North Sea } \\
\text { Irish Sea } \\
\text { English Channel }\end{array}$ & $\begin{array}{c}10^{-5}-10^{-6} \\
10^{-5} \\
10^{-5}\end{array}$ & $\begin{array}{c}10^{-3}-10^{-4} \\
10^{-3} \\
10^{-3}\end{array}$ & $\begin{array}{l}10^{-2} \\
10^{-2} \\
10^{-2}\end{array}$ & $\begin{array}{l}\text { Geffen et al. } 2007 \\
\text { Calculated from Harding and } \\
\text { Talbot } 1973 \text { and Talbot } 1977\end{array}$ \\
\hline $\begin{array}{l}\text { Winter flounder (Pseudopleuronectes americanus, } \\
\text { Pleuronectidae) }\end{array}$ & All or whole & $10^{-5}-10^{-6}$ & $10^{-3}-10^{-4}$ & $10^{-2}$ & Rose et al. 1996 \\
\hline Atlantic eel (Anguilla Anguilla, Anguillidae) & All or whole & $10^{-4}$ & $3.10^{-4}$ & 0.3 & Bonhommeau et al. 2009 \\
\hline Atlantic bluefin tuna (Thunnus thynnus, Scombridae) & All or whole & $10^{-4}$ & $4.10^{-4}$ & 0.3 & Simon et al. 2012 \\
\hline Pacific bluefin tuna (Thunnus orientalis, Scombridae) & All or whole & $6-8.10^{-5}$ & $4.10^{-4}$ & $0.1-0.2$ & $\begin{array}{l}\text { Iwata et al. 2012, Polacheck et al. } \\
\text { 1997, Whitlock et al (2012) }\end{array}$ \\
\hline Southern bluefin tuna (Thunnus macoyii, Scombridae) & All or whole & $2.10^{-5}$ & $4.10^{-4}$ & 0.06 & Tsuji (1998) \\
\hline
\end{tabular}

* Survival rates are estimated with important associated variability and estimation error. 
Table 2: Analysis of food limitation in temperate and subarctic juvenile flatfish: species, location, methods and conclusions

\begin{tabular}{|c|c|c|c|c|}
\hline Species & Area & Approach & Conclusion & Reference \\
\hline Common sole & & Experimental & Food limitation & Fonds and Saksena 1977 \\
\hline Common sole & & Experimental & Food limitation & Fonds et al. 1989 \\
\hline $\begin{array}{l}\text { Plaice, European Flounder (Platichthys flesus, } \\
\text { pleuronectidae) }\end{array}$ & & Experimental & Food limitation & Fonds et al. 1992 \\
\hline Stone flounder (Kareius bicoloratus, Pleuronectidae) & & Experimental & Food limitation & Malloy et al. 1996 \\
\hline $\begin{array}{l}\text { California flounder (Paralichthys californicus, } \\
\text { Pleuronectidae) }\end{array}$ & & Experimental & Food limitation & López-Rasgado and Herzka 2009 \\
\hline Plaice & & Experimental & Food limitation & Ciotti et al. 2010 \\
\hline Plaice & & Experimental & Link to prey availability & Selleslagh and Amara 2013 \\
\hline Plaice & 0 & Experimental & Link to prey availability & Wennhage and Gibson 1998 \\
\hline Winter flounder & 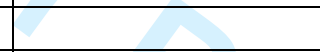 & Experimental & Link to prey availability & Phelan et al. 2001 \\
\hline $\begin{array}{l}\text { Senegalese sole (Solea senegalensis, Soleidae), Common } \\
\text { sole }\end{array}$ & Iberian shelf & Field, individual & No food limitation & Fonseca et al. 2006 \\
\hline Winter flounder & New Jersey, USA & Field, individual & No food limitation & Curran and Able 2000 \\
\hline $\begin{array}{l}\text { Common sole, Plaice, Dab (Limanda limanda, } \\
\text { Pleuronectidae) }\end{array}$ & English Channel & Field, individual & No food limitation & Gilliers et al. 2004 \\
\hline Plaice & English Channel & Field, individual & No food limitation & Selleslagh and Amara 2013 \\
\hline Common sole & French coasts & Field, individual & No food limitation & Gilliers et al. 2006 \\
\hline Common sole, Plaice, Dab & English Channel & Field, population & No food limitation & Amara 2004 \\
\hline Senegalese sole, Common sole & Iberian shelf & Field, population & No food limitation & Vinagre and Cabral 2008 \\
\hline Common sole & Bay of Biscay & Field, population & No link to prey availability & Amara et al. 2000 \\
\hline $\begin{array}{l}\text { American plaice (Hippoglossoides platessoides, , } \\
\text { Pleuronectidae) }\end{array}$ & Gulf of St Lawrence & Field, population & No link to prey availability & Swain and Morin 1996 \\
\hline Common sole & North Sea & Field, population & No link to prey availability & Rogers, 1994 \\
\hline Plaice & North Sea & Field, population & No link to prey availability & Van der Veer et al. 2000b \\
\hline Senegalese sole, Common sole & Iberian shelf & Field, population & No link to prey availability & Fonseca et al. 2010 \\
\hline English sole (Parophrys vetulus, Pleuronectidae) & Washington, USA & Field, population & No link to prey availability & Shi et al. 1997 \\
\hline English sole & Washington, USA & Field, population & No link to prey availability & Chittaro et al. 2009 \\
\hline Common sole & Bay of Biscay & Field, individual & Partial food limitation & Amara and Galois 2004 \\
\hline Plaice & Wadden Sea & Field, individual & Food limitation & Karakiri et al. 1989 \\
\hline Plaice & North Sea & Field, individual & Food limitation & Van der Veer et al. 2001 \\
\hline Plaice & Irish Sea & Field, individual & Food limitation & Ciotti et al. 2013 \\
\hline Common sole & Bay of Biscay & Field, population & Food limitation & Laffargue et al 2007 \\
\hline Common sole, Plaice; European flounder & Western Europe & Field, population & Food limitation & Freitas et al. 2012 \\
\hline Plaice & North Sea & Field, population & Food limitation & Teal et al. 2008 \\
\hline
\end{tabular}




\begin{tabular}{|c|c|c|c|c|}
\hline Plaice & North Sea & Field, population & Food limitation & Van der Veer et al. 2010 \\
\hline Plaice & Baltic Sea & Field, population & Food limitation & Pihl et al. 2000 \\
\hline Plaice & North Sea & Field, population & Food limitation & Ciotti et al., 2013 \\
\hline Plaice & Irish Sea & Field, population & Food limitation & de Raedemacker et al., 2011 \\
\hline Plaice & Wadden Sea & Field, population & Food limitation & van der Veer and Witte 1993 \\
\hline Plaice & Irish Sea & Field, population & Food limitation & Nash and Geffen 2000 \\
\hline Plaice & Irish Sea & Field, population & Food limitation & Nash et al. 2007 \\
\hline Common sole & Bay of Biscay & Field, population & Link to prey availability & Le Pape et al. 2003c \\
\hline Common sole & Bay of Biscay & Field, population & Link to prey availability & Marchand and Masson, 1989 \\
\hline Winter flounder & Connecticut, USA & Field, population & Link to prey availability & Howell et al. 1999 \\
\hline Pleuronectiforms & Eastern Bering Sea & Field, population & Link to prey availability & McConnaughey and Smith, 2000 \\
\hline American plaice & Bering Sea & Field, population & Link to prey availability & Walsh 1996 \\
\hline Common sole, Plaice & English Channel & Field, population & Link to prey availability & Riou et al. 2001 \\
\hline Common sole & Bay of Biscay & Field, population & Link to prey availability & Le Pape et al 2007 \\
\hline Common sole & Bay of Biscay & Field, population & Link to prey availability & Nicolas et al. 2007 \\
\hline Common sole, European flounder & Iberian shelf & Field, population & Link to prey availability & Costa and Bruxelas 1989 \\
\hline Common sole, European flounder & Iberian shelf & Field, population & Link to prey availability & Vinagre et al. 2005 \\
\hline Senegalese sole, Common sole & Iberian shelf & Field, population & Link to prey availability & Vinagre et al. 2006 \\
\hline Bastard halibut (Paralichthys olivaceus, , Pleuronectidae) & Northwestern Japan & Field, population & Link to prey availability & Fujii and Noguchi 1995 \\
\hline Common sole & North Sea & Field, population & Link recruitment / food & Leakey et al. 2008 \\
\hline Common sole & Bay of Biscay & Field, population & Link recruitment / food & Le Pape et al. 2003a \\
\hline Common sole & Bay of Biscay & Field, population & Link recruitment / food & Le Pape et al. 2003b \\
\hline Common sole & Bay of Biscay & Field, population & Link recruitment / food & Le Pape et al. 2003d \\
\hline Common sole & Western Europe & Field, population & Link recruitment / food & Le Pape et al. 2013 \\
\hline Common sole & Bay of Biscay & Field, population & Link recruitment / food & Kostecki et al. 2010 \\
\hline Common sole & Gulf of Lions & Field, population & Link recruitment / food & Salen Picard et al. 2002 \\
\hline Common sole & Gulf of Lions & Field, population & Link recruitment / food & Darnaude et al. 2004 \\
\hline Pleuronectiforms & Gulf of Lions & Field, population & Link recruitment / food & Darnaude et al. 2005 \\
\hline Senegalese sole, Common sole & Iberian shelf & Field, population & Link recruitment / food & Vinagre et al. 2008 \\
\hline Pleuronectiforms & Iberian shelf & Field, interspecific & Link to prey availability & Wouters and Cabral 2009 \\
\hline Pleuronectiforms & Iberian shelf & Field, interspecific & Food partitioning & Cabral et al. 2007 \\
\hline Senegalese sole, Common sole & Iberian shelf & Field, interspecific & Food partitioning & Cabral and Costa 1999 \\
\hline Senegalese sole, Common sole & Iberian shelf & Field, interspecific & Food partitioning & Cabral 2000 \\
\hline Common sole, Plaice, Dab & English Channel & Field, interspecific & Food partitioning & Amara et al. 2001 \\
\hline Pleuronectiforms & Gulf of Lions & Field, interspecific & Food partitioning & Darnaude et al. 2001 \\
\hline Common sole, Plaice & English Channel & Field, interspecific & Food partitioning & Kostecki et al. 2012 \\
\hline Flounder, Common sole & Iberian shelf & Field, interspecific & Food partitioning & Vinagre et al. 2005, \\
\hline
\end{tabular}


2 Fig. 1: Location of the regional seas in Western Europe where many of the studies in this

3 review have taken place.

4

5 Fig. 2: Comparison of the theoretical growth curve of the common sole after settlement

6 during their first year (grey line) and simulations of sampling carried out each month for 710,000 (out of $1,000,000$ ) juvenile common sole that experienced a) no food limitation and b) 8 food-limited conditions (i.e., maximal length reduced by $20 \%$ in the model).

9

10 Fig. 3: Processes involved in the food limitation hypothesis: consequences of the limited 11 trophic capacity of nursery habitats during the settlement and post-settlement period on the 12 recruitment variability of marine fishes (pluriannual variability in cohort abundance is 13 represented for two different life stages, larval / large juveniles, before and after the stage of 14 food limitation).

15

16 
1 Figure 1

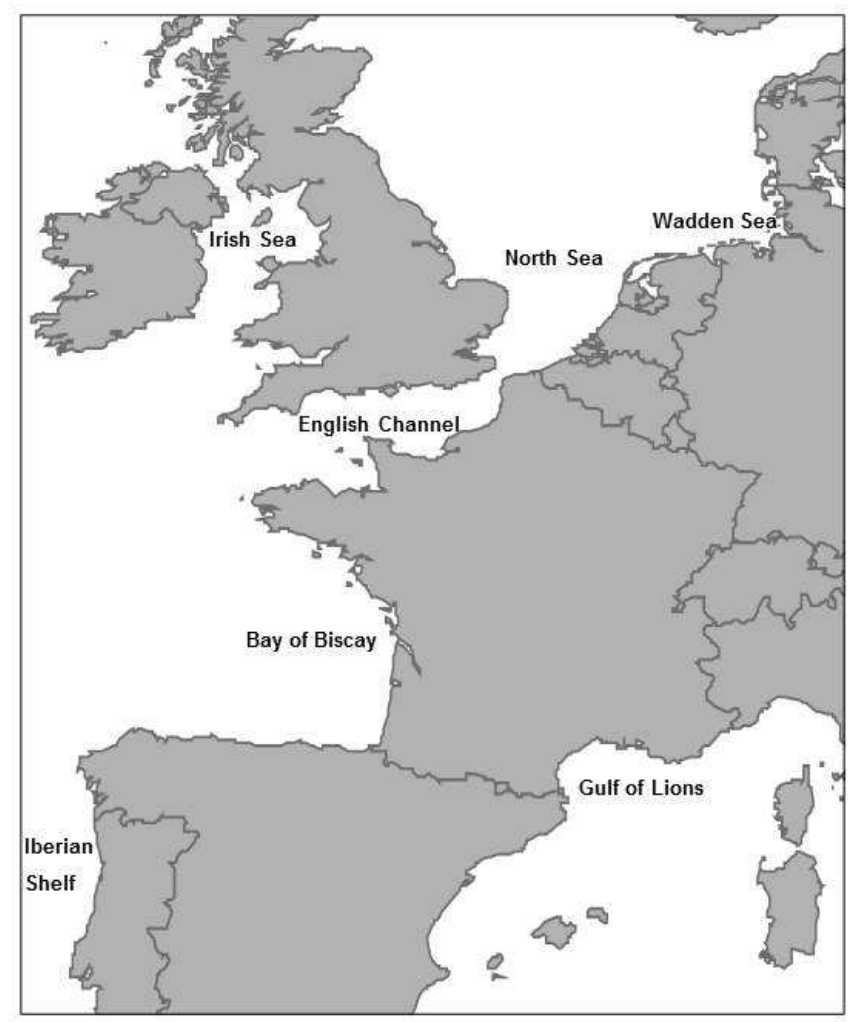

2 
$1 \quad$ Figure 2
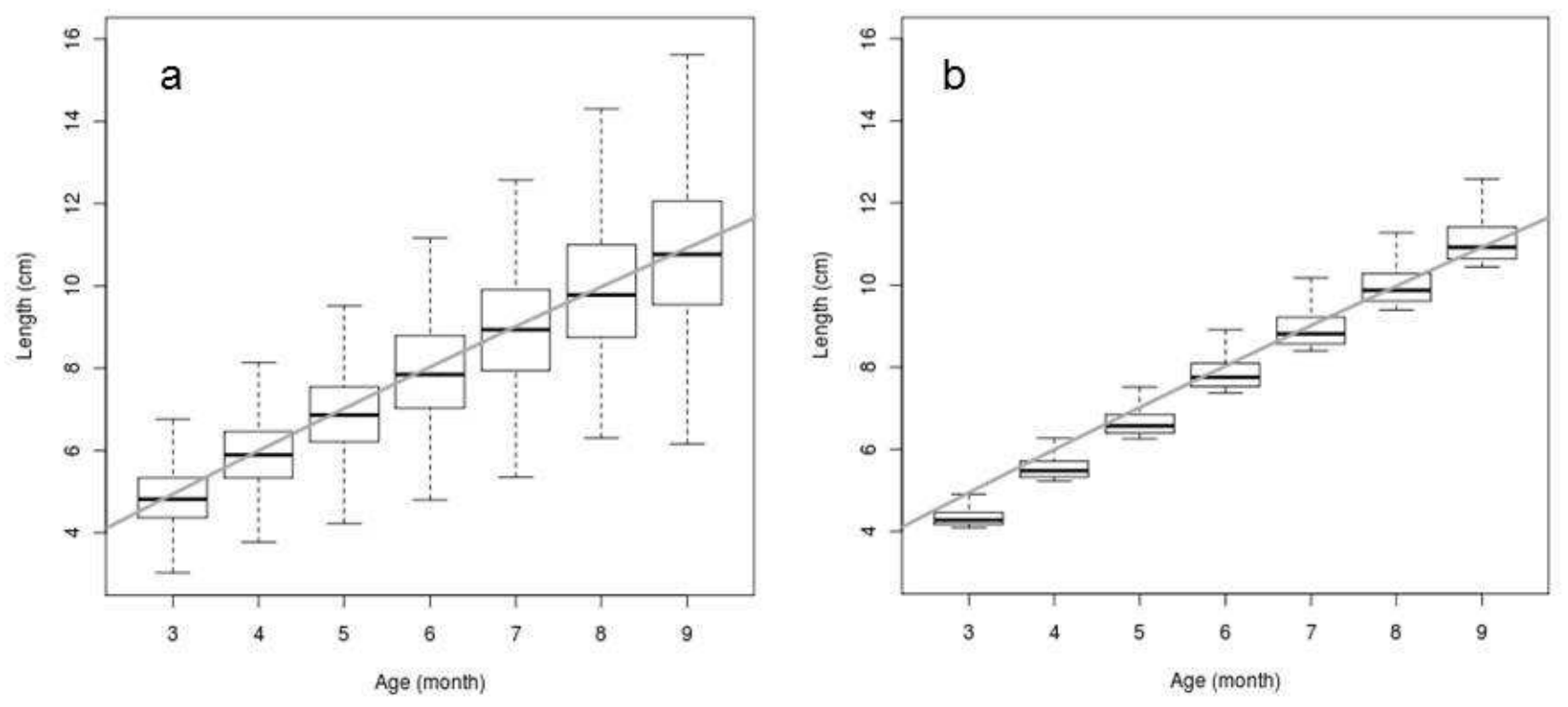
1 Figure 3

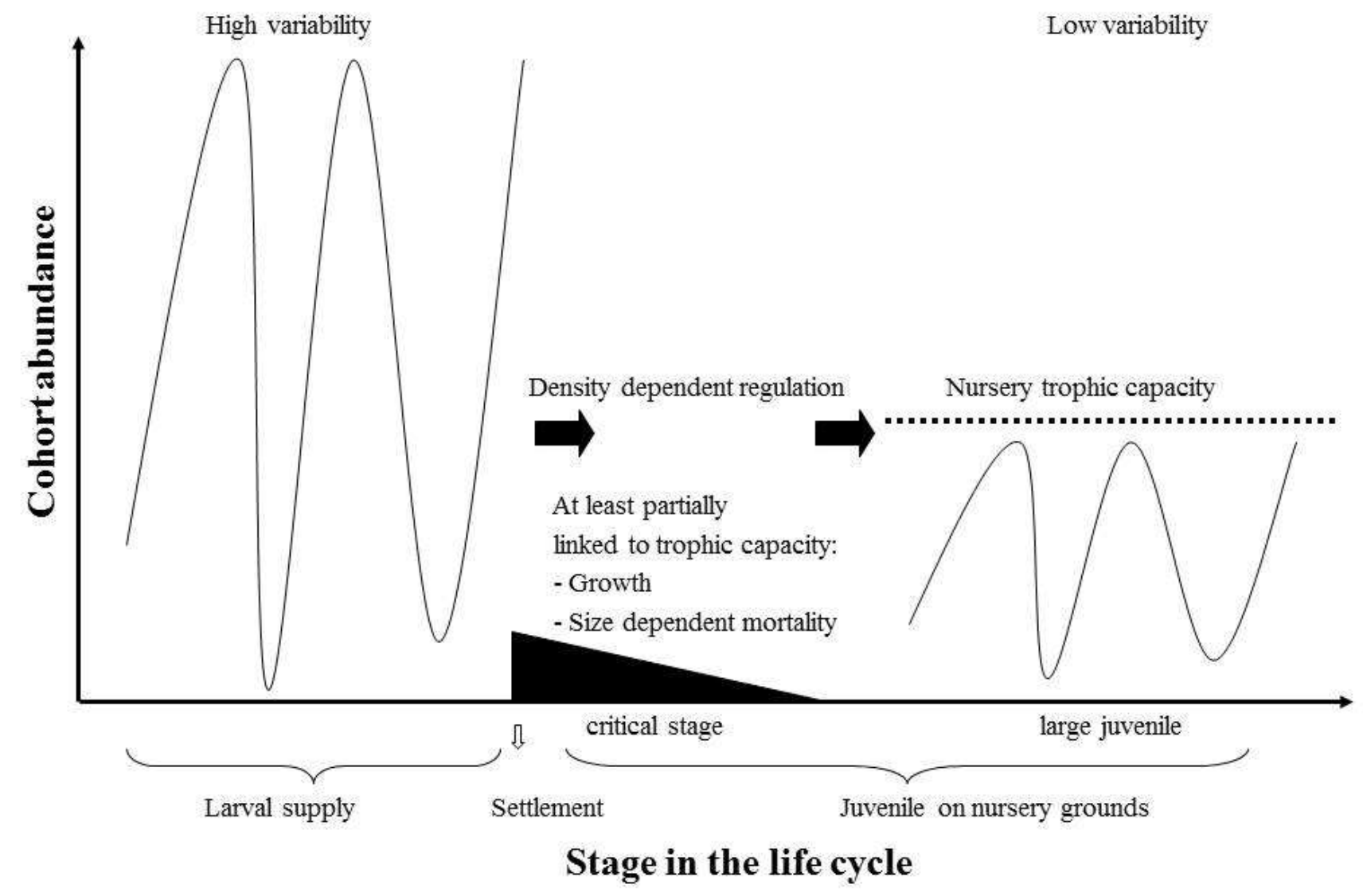

